\title{
Do corporate insiders trade on future stock price crash risk?
}

\author{
Guanming $\mathrm{He}^{1}$ (D) $\cdot$ Helen Mengbing Ren $^{2} \cdot$ Richard Taffler $^{3}$
}

Published online: 21 September 2020

(c) The Author(s) 2020

\begin{abstract}
We explore whether firm managers trade on future stock price crash risk. This depends on managers' ability to assess future crash risk, and on whether the expected payoff is greater than the expected costs associated with potential reputation loss and litigation risk. We find that insider sales are positively associated with future crash risk, which is consistent with managers' trading on crash risk for personal gain. We also find that managers take advantage of high information opacity to pursue crash-risk-based insider sales more aggressively, but are less able to capitalize on this in the case of financial constraints or post-SOX.
\end{abstract}

Keywords Insider selling · Managerial opportunism · Financial constraints · Information asymmetry $\cdot$ SOX

JEL Classification $\mathrm{G} 14 \cdot \mathrm{G} 30 \cdot \mathrm{M} 41$

\section{Introduction}

The literature documents that managers tend to trade on the basis of their advance knowledge of corporate bad news at the expense of uninformed outside investors (e.g., Ke et al. 2003; Dechow et al. 2016). Insiders' motivation for such information-based sales is to avoid personal losses associated with the announcement of negative firm news which is information previously unknown by outsiders.

In contrast, our paper examines whether corporate insiders trade on future stock price crash risk, rather than on specific bad news events that insiders know about exactly via their private information. It cannot be taken for granted that managers can recognize future stock price crash risk as well, which requires their ability to extrapolate from their inside knowledge and information. Thus, ex ante, it is unclear if insiders are able to anticipate stock price crash risk. Furthermore, whether insiders will actually trade on future crash risk also depends on how they perceive the likelihood of whether the payoff from such strategic trading will be greater than the costs associated with potential reputation loss and threat of

Guanming He

guanming.he@durham.ac.uk

1 Durham University Business School, Durham University, Durham, UK

2 University of Liverpool Management School, University of Liverpool, Liverpool, UK

3 Warwick Business School, University of Warwick, Coventry, UK 
litigation. Such perceived benefits vis-à-vis costs, due to the unique nature of crash risk, are distinct from those from trading on corporate events, especially when looking at crash-riskbased insider sales made based on a relatively long horizon. For these reasons, whether insider sales are associated with future stock price crash risk is an important, open question worthy of exploring.

Extant studies (e.g., Jin and Myers 2006; Hutton et al. 2009) attribute stock price crash risk to managerial hoarding of bad news. In particular, managers have incentives to hide bad news for career and short-term compensation reasons (Jin and Myers 2006; Kothari et al. 2009; Baginski et al. 2018). Nonetheless, there exists an upper limit where it becomes too costly or difficult for managers to further withhold the bad news, but usually they cannot anticipate when this point will arrive (He 2015). Once this threshold point is reached, it will not be possible to contain all the stockpiled bad news, leading to an abrupt, dramatic collapse in stock price, that is, a stock price crash (Chen et al. 2001; Hutton et al. 2009). ${ }^{1}$ Accordingly, stock price crash risk refers to the likelihood of a stock price crash due to bad news hoarding (e.g., Jin and Myers 2006; Hutton et al. 2009). ${ }^{2}$ Such bad news withheld could be of any kind that, once released, would lead to a stock price fall.

On the other hand, if corporate bad news is released to the market on a timely basis and the stock price falls, there will be no stock mispricing and no incentive for informed insider trades. Put differently, informed insider sales are likely only when the disclosure of bad news is delayed with stock prices consequently overstated; nonetheless, it is difficult to empirically identify whether a particular piece of bad news had been withheld before being released. Therefore, compared with various corporate bad news events studied in the prior insider-trading literature, stock price crash risk provides a powerful, generalized setting in which to examine managerial motives behind opportunistic insider sales.

Though managers usually cannot predict exactly the point at which their firm's stock price will actually collapse, they may still be able to assess the likelihood of such an event. The aim of our study is to link insider sales with future stock price crash risk. Specifically, we investigate whether managers' anticipation of future stock price crash risk leads them to sell down their firm stocks.

Insider sales can also be driven by insiders' liquidity needs or for portfolio diversification purposes (Lustgarten and Mande 1995; Carpenter and Remmers 2001; Frankel and Li 2004), and it is difficult for investors to distinguish information-motivated sales from liquidity- or diversification-motivated sales (Beneish and Vargus 2002). As a result, legal and reputational risks arising from insider sales are expected to be low, thus providing insiders with incentives to engage in opportunistic stock sales. Furthermore, since future crash risk is uncertain by nature, it is hard for outsiders to identify insider trades that are based on future crash risk. Therefore, we predict that insiders have an incentive to sell their stocks in anticipation of high future crash risk. Our results confirm this expectation.

\footnotetext{
1 A stock price crash is conceptually different from an ordinary drop in stock price. Stocks with prices declining gradually over time may have very low crash risk.

${ }^{2} \mathrm{Bad}$ news hoarding is usually regarded as the fundamental driver of stock price crash risk (e.g., Chen et al. 2001; Jin and Myers 2006; Hutton et al. 2009; Kim et al. 2011a, b; He 2015); the more bad news corporate insiders hoard, the higher the crash risk of their firm. Bad news events per se would trigger stock price crashes only when the following three conditions all hold: (1) the bad news is severe enough; (2) the market cannot anticipate such bad news in advance; (3) insiders do not warn the market of the bad news. Hence, bad news events do not necessarily lead to stock price crashes, even though on some occasions they do; it is worth further noting that, once bad news is revealed to the public, stock price crash risk will become lower as the stock price declines.
} 
Our empirical analysis covers stock sales made by top managers (i.e., officers and directors) of a large sample of U.S. firms over the period 1993-2013. Because insiders tend to trade on varied bad news events, we control for future stock returns and future trading volume, along with a wide array of determinants of insider sales, in all our regression analyses. Consistent with our hypothesis, we find strong evidence that insider sales are associated with 15-month-ahead crash risk. Our findings are robust to different measures of crash risk and potential correlated omitted variable(s). We also demonstrate that reverse causality, i.e., that insider selling might affect stock price crash risk, is unlikely to explain our results. We conduct further analysis of the positive association between insider trades and future stock price crash risk, and find that this association is weaker for financially constrained firms, stronger for firms that have a high degree of information asymmetry with outsiders, and less pronounced after the implementation of SOX.

Our study contributes to both insider trading literature and crash risk literature. The literature on informed insider trading finds that insiders tend to trade on their foreknowledge of a wide range of bad news events. ${ }^{3}$ We believe our study advances this stream of literature along the following four dimensions:

First, our paper extends this literature by linking insider sales directly with the future stock price crash risk that results from bad news hoarding. In contrast to previous work which mainly examines insider trades made within two quarters ahead of bad news events, we focus on the risk of a stock price crash as anticipated by insiders on a relatively longer horizon, and illuminate the underlying motivation behind informed trades made based on crash risk. $^{4}$

Second, the prior literature on informed insider trades explores a range of corporate news events known exactly by managers. By contrast, we focus on stock price crash risk per se, which managers need to make efforts to deduce before trading on it. Furthermore, managers' perceived benefits from trading on future crash risk vis- $a$-vis the perceived costs should inherently differ to those from trading on future corporate events which in themselves constitute insider information. In developing our hypotheses, our study adds to the insider trading literature by providing insights into the benefits vis-à-vis costs associated with informed insider trades.

Third, stock price crash risk provides a more powerful, generalized setting than the extant insider trading literature to examine the incentives for insider sales. This is first

\footnotetext{
3 These include bankruptcies (e.g., Gosnell et al. 1992; Seyhun and Bradley 1997), dividend announcements (e.g., John and Lang 1991), SEC enforcement actions (e.g., Beneish 1999; Johnson et al. 2009; Thevenot 2012), disclosures of internal control weaknesses (Skaife et al. 2013), public disclosures of negative Securities and Exchange Commission (SEC) comment letters (Dechow et al. 2016), and earnings disappointments (e.g., Beneish and Vargus 2002; Ke et al. 2003; Darrough and Rangan 2005; Badertscher et al. 2011; Billings and Cedergren 2015), among others.

4 There are two reasons why we focus on insider sales in this study. First, a stock price increase as a result of insider purchases would only result in opportunity costs, not real damages, to an investor who fails to buy the stocks that had been purchased by insiders (Niehaus and Roth 1999; Cheng and Lo 2006). In contrast, when insider sales are followed by a price decline especially a stock price crash, outside investors holding stocks of the firm would suffer substantive losses. Therefore, in general, investors are much concerned about insider sales, especially those made on the basis of future crash risk, rather than about insider purchases. Second, insider purchases are far fewer than insider sales in practice because of the prevalent practice of companies granting stocks and stock options to corporate insiders. Further, insiders can sell their own stocks on a relatively long horizon in advance of their anticipated future crash risk. This selling strategy would subject insiders to relatively low litigation risk and is thus more likely to be utilized by them for fulfilling self-serving incentives. Therefore, insider sales made in a longer-horizon anticipation of future crash risk should deserve more attention and scrutiny by investors, which is the focus of our study.
} 
because substantive stock-price falls will not necessarily follow the particular bad news events examined in the prior insider-trading research if the market is warned about, or is able to anticipate, these events in advance. On the other hand, if bad news is released timely to the public and is equitably known to both insiders and outsiders, no informed insider sales will take place despite the stock price decline associated with the bad news. Crash risk, the risk of a dramatic stock price plunge, potentially results from managerial withholding of a wide range of adverse corporate information. Moreover, the payoff to insiders from trading on the risk of an abrupt, significant stock-price decline is likely to be considerably larger than the payoff to stock sales made based on an ordinary stock price drop. By showing that insider sales are positively associated with future stock price crash risk, we are able to substantiate the prevalence of such opportunistic managerial trading behavior.

Fourth, to the extent that insiders can influence whether, when, and how corporate news is released, insider trades and the future news events that managers trade on are endogenously determined, which the literature on informed insider trades arguably does not take into account. Our study explicitly acknowledges this endogeneity concern and seeks to mitigate it.

Our study also contributes to the extant crash risk literature. This literature (e.g., Francis et al. 2016; Lee and Wang 2017; Kao et al. 2020) focuses predominantly on the determinants of stock price crash risk, with very little attention paid to the implications of crashrisk exposure for managers' decision-making. We fill this void in the literature by showing how firm crash-risk exposure leads to decisions by insiders to sell down their stocks to extract private benefits.

The rest of the paper proceeds as follows. In Sect. 2, we develop our testable hypotheses. Section 3 describes the data sources and variable measures. Section 4 presents the research design. Section 5 discusses the results. Section 6 conducts additional analysis, and Sect. 7 concludes.

\section{Hypothesis development}

\subsection{The association between insider sales and future stock price crash risk}

Prior research shows that insiders actively trade on their foreknowledge of future bad news events. For instance, Seyhun and Bradley (1997) find insider sales occur prior to the filing date of bankruptcy petitions. John and Lang (1991) document how insiders in growth firms tend to sell their shares prior to dividend initiation announcements that signal reduced growth opportunities. Skaife et al. (2013) find that the profitability of insider selling is particularly high in the years leading up to disclosures of material internal control weaknesses. Beneish (1999), Johnson et al. (2009), Thevenot (2012), and Agrawal and Cooper (2015) find that insiders sell down substantially more of their stocks before revelations of accounting irregularities. Dechow et al. (2016) show that insider sales are significantly higher prior to the public release of SEC comment letters relating to aggressive revenue recognition. Ke et al. (2003) find that insider sales increase in advance of a break in a string of consecutive increases in quarterly earnings. Collectively, this strand of literature suggests that insiders can foresee future bad news events, and that they trade intensively to exploit their information advantage. To the extent that managers are competent, we posit that insiders can appraise the likelihood of a future stock price crash for purpose of selling down their stock holdings to avoid the associated monetary losses. 
Managers, who run corporate businesses and possess varied types of private information, have discretion on how to publicly disclose their firm's operational status, business strategies, risks, performance, prospects, and any other value-relevant information. They can disclose this set of inside information strategically so that outside investors will find it difficult to assess future crash risk in the same way insiders can. Consequently, asymmetry of information about future crash risk arises between insiders and outsiders, thereby making crash-risk-based insider sales beneficial for insiders but harmful to outsider investors.

On the other hand, the risks and costs associated with crash-risk-based insider sales are likely to be low for insiders for two reasons. First, insider sales can be attributed either to insiders' exploitation of negative private information (e.g., Lakonishok and Lee 2001; Kallunki et al. 2018) or to their liquidity or investment portfolio diversification needs (Lustgarten and Mande 1995; Carpenter and Remmers 2001; Frankel and Li 2004). It is often difficult for investors to distinguish information-motivated sales from liquidity- or diversification-motivated sales (Beneish and Vargus 2002); even if investors can, insiders may still defend themselves against reputational and legal risks by arguing that their information-driven sales were not informationally motivated. As such, the expected costs to insiders in making informed stock sales are low. Second, due to a firm's changing external environment and internal business operations, the extent of future stock price crash risk could be of uncertainty even to corporate insiders. Trading on a piece of information that is, by nature, uncertain entails relatively low litigation risk for insiders. Therefore, managers should have incentives to engage in insider sales based on future crash risk, given that the expected costs will likely be lower than the expected payoff. Such a payoff (i.e., losses avoided by selling stocks in advance) is potentially more attractive to insiders compared to the payoff from stock sales made based on an ordinary stock-price decline. These arguments lead to our first hypothesis stated in the alternative form as follows:

H1 Insider sales are positively associated with future stock price crash risk.

The more strongly insider sales are positively associated with future stock price crash risk (i.e., when insider sales vary to a larger extent in response to future crash risk), the more pronounced the crash-risk-based insider sales are. In the next section, we further examine the cross-sectional variation in the crash-risk-based insider sales.

\subsection{Cross-sectional variation in the association between insider sales and future crash risk}

Financial constraints refer to frictions that prevent a firm from funding its desired investments (Lamont et al. 2001). Financially constrained firms require external funds to meet their investment needs. Prior studies (e.g., Lakonishok and Lee 2001; Jeng et al. 2003; Fidrmuc et al. 2006) document that insider selling could by itself convey unfavorable information to the market, leading to a fall in share price. Because of the information effect of insider sales, financially constrained firms, if involved in insider sales, will find it more difficult to raise external capital for investments and operations (Campello et al. 2010; Ataullah et al. 2014), and consequently, will become more financially constrained. Thus, the costs for managers to pursue crash-risk-based insider sales are expected to be greater in the case of financial constraints. Confronted with financial constraints, insiders should refrain from trading on future stock price crash risk. This leads to our second hypothesis: 
$\mathrm{H} 2 \mathrm{a}$ The positive association between insider sales and future stock price crash risk is less pronounced for firms that face financial constraints.

Nonetheless, if insiders do not care about their long-term compensation and career prospects, they will not worry about the increased financial constraints resulting from insider sales. Under this premise, higher crash risk, which likely arises due to exacerbated financial constraints (He and Ren 2020), will induce higher insider selling. Thus, we allow for the opposite hypothesis as follows:

H2b The positive association between insider sales and future stock price crash risk is more pronounced for firms that face financial constraints.

Insider trading is fundamentally driven by insiders' information advantage over outside investors. Theory (e.g., Grossman and Stiglitz 1980; Glosten and Milgrom 1985; Kyle 1985; Huddart and Ke 2007) suggests that the greater the magnitude of information asymmetry between insiders and outsiders, the higher the trading profits insiders can reap from their stock trades. Consistent with this notion, Frankel and Li (2004) find evidence that the association between insider sales and subsequent returns, which is employed as a proxy for the profitability of insider trades, is weaker for firms that experience an increase in financial statement informativeness and in analyst following. Similarly, Lakonishok and Lee (2001) show that firm size, an inverse measure of information asymmetry, is negatively associated with the extent to which insider trades predict future stock returns. Aboody and Lev (2000) predict and find that an increase in information asymmetry between insiders and outsiders, resulting from research and development activities, allows insiders to gain higher profits from their stock trades. Given the higher trading profits that insiders can earn from firms with high information asymmetry, insiders in such firms should have stronger motives to trade aggressively in anticipation of high future crash risk. Our third hypothesis thus follows:

H3 The positive association between insider sales and future stock price crash risk is stronger for firms with greater information asymmetry between insiders and outsiders.

The Sarbanes-Oxley Act (SOX) was implemented in 2002 with the objective of improving corporate governance and financial reporting quality, and appears generally to have achieved this goal. For example, the accuracy of analyst earnings forecasts has increased (Arping and Sautner 2013), and earnings quality is enhanced (Iliev 2010), both consistent with SOX rendering corporate information less opaque. Similarly, by mandating management evaluation, and independent audit, of internal control effectiveness, SOX has lowered information risk and cost of equity for firms (Ashbaugh-Skaife et al. 2009).

We predict that SOX would have reduced opportunistic crash-risk-driven insider sales for the following reasons. First, separation of ownership and control induces incentive misalignment between managers and shareholders, motivating managers to extract rents from shareholders (Jensen and Meckling 1976). One route for managerial rent extraction is insider trading whereby insiders (i.e., informed traders) profit at the expense of shareholders (i.e., uninformed traders) (e.g., Seyhun 1986; Fishman and Hagerty 1992; Bettis et al. 2000; Jagolinzer et al. 2011). Given that corporate governance is intended to align managers' interests with those of shareholders, it follows that strong corporate governance should mitigate opportunistic insider sales that are detrimental to shareholders. In this vein, 
if SOX has enhanced corporate governance, insiders should be less likely to trade on future crash risk after the enforcement of SOX.

Second, low information opacity reduces the profitability of insider trades (e.g., Kyle 1985; Huddart and Ke 2007). If SOX has improved disclosure transparency and financial reporting quality for firms, information asymmetry between insiders and outsiders should be lower. As a result, insiders would profit less from their informed trades, and accordingly, have weaker incentives to dispose of their stocks on the basis of their assessed future crash risk.

Third, the legal and reputational costs associated with insider sales are expected to be greater post SOX, which thereby disincentivizes corporate insiders from engaging in crash-risk-based stock sales. Based on the above arguments, we expect SOX to have weakened insiders' incentives to trade on future stock price crash risk, and establish our fourth hypothesis:

H4 The positive association between insider sales and future stock price crash risk is weaker after the implementation of SOX.

\section{Sample and variable construction}

\subsection{Data sources and sample}

Our insider trading data are obtained from the Thomson Financial Insider Research Services Historical Files. We restrict our insider trading transactions to open market trades, exclusive of non-open market trades such as option grants, option exercises, dividend reinvestments, stock transfers among family members, and pension transactions (Huddart and Ke 2007; Huddart et al. 2007). ${ }^{5}$ We further limit our insider trading transactions to those by officers and directors only, excluding those by non-officer employees who are unlikely to impact major corporate decisions. ${ }^{6}$ For each firm, we sum all purchases and sales by managers in the fiscal years of interest to allow us to focus on the actions of the management team in aggregate. ${ }^{7}$

We obtain our financial analyst data from the Institutional Brokers Estimate System (I/B/E/S) database. Other data are taken from the Center for Research in Security Prices (CRSP) and Compustat. Our sample period ranges from 1993 to 2013. We end our sample period in 2013 because the institutional trading data required for constructing our dedicated

\footnotetext{
${ }^{5}$ Compared with buying put options, timing stock sales could be a more flexible tool for insiders to avoid losses from potential stock price crashes. According to previous studies (e.g., Amin and Lee 1997; Hyland et al. 2003), firms with optioned stocks are fewer than those with non-optioned stocks, hence option trades by insiders are less prevalent than stock trades by insiders in the capital market. Thus, consistent with prior research (e.g., Cheng and Lo 2006; Huddart and Ke 2007; He and Marginson 2020), we focus on insiders' stock trades in this paper.

${ }^{6}$ Our results remain qualitatively unchanged if we use the insider trades by CEOs, CFOs, and chairmen of boards (namely, senior insiders) only. We do not compare trades by insiders, who are in different positions, in our empirical analysis because of likely sharing of inside information among the insiders.

7 For a given firm in a fiscal year, some insiders might be selling while others might be buying. In this case, insider purchases are subtracted from insider sales to reflect the net direction of insider sales in that fiscal year. In so doing, we control for the confounding effects of insider purchases on our regression analysis in which insider selling is the dependent variable.
} 
institutional ownership variable are only available for us for the period before $2014 .^{8} \mathrm{We}$ restrict our sample to firms with the necessary data to allow us to construct the variables we need for our empirical tests. Our final sample for testing the association between insider sales and future stock price crash risk comprises 32,326 firm-year observations for 7135 unique firms. Table 1 reports summary statistics for all the variables which are used in our hypothesis tests and defined in the "Appendix".

\subsection{Measures of firm-specific stock price crash risk}

As with prior research (e.g., Chen et al. 2001; Jin and Myers 2006; Hutton et al. 2009; Kim et al. 2011a, b; Callen and Fang 2015; DeFond et al. 2015), we focus solely on firmspecific stock price crash risk; crash risk that is ascribed to market-wide factors is beyond the scope of this study. We employ three measures of stock price crash risk. The first is the likelihood of negative, extreme firm-specific weekly returns over a fiscal year (namely, crashrisk) as per Hutton et al. (2009). crashrisk equals 1 if a firm experiences one or more firm-specific weekly returns falling 3.2 standard deviations below the mean firm-specific weekly return over a fiscal year, and 0 otherwise. ${ }^{9}$ Our second crash risk measure (namely, ncskew) follows Chen et al. (2001) and is the negative third moment of each stock's firmspecific weekly returns. The third measure of crash risk (duvol) is the down-to-up variance of firm-specific weekly returns as per Chen et al. (2001). duvol equals the standard deviation of "down"-week firm-specific weekly returns (scaled by the number of "down"-weeks minus one), divided by the standard deviation of "up"-week firm-specific weekly returns (scaled by the number of "up"-weeks minus one) over a fiscal year. The firm-specific weekly returns measure used in calculating crashrisk, ncskew, and duvol follows Kim et al. (2011a), and is adjusted for market-wide factors. In line with prior literature on stock price crash risk (Hutton et al. 2009; Kim et al. 2011a, b; Callen and Fang 2015; DeFond et al. 2015), high values of crashrisk, ncskew, and duvol proxy for a high likelihood of a stock price crash. In anticipation of high stock price crash risk, insiders would have a tendency of selling their stocks to avoid monetary losses associated with a stock price crash.

In line with Hutton et al. (2009), our main tests are based primarily on the crashrisk variable; the other two crash risk measures are used for robustness purposes. As reported in Table 1 , the mean value of crashrisk is 0.1791 , indicating that firm-specific stock price crash risk for a fiscal year amounts to $17.91 \%$. This is close to that reported by Hutton et al. (2009) though they use a shorter sample period than we do. The correlation matrix (not reported for simplicity) reveals that crashrisk is highly, positively correlated with ncskew and duvol (0.411 and 0.392), respectively.

\footnotetext{
${ }^{8}$ We thank Brian Bushee for sharing the institutional investor classification data which we use to derive the variable for dedicated institutional stock ownership.

${ }^{9}$ Our inferences for the hypothesis tests remain the same if we re-define the negative, extreme firm-specific weekly returns as being lower than the mean firm-specific weekly return by 3.1 , or 3.3 , standard deviations. We also obtain similar results when using the number of crash weeks over a fiscal year to measure crash risk.
} 
Table 1 Summary statistics

\begin{tabular}{|c|c|c|c|c|c|c|c|}
\hline Variables & $\begin{array}{l}\text { No. of firm- } \\
\text { years }\end{array}$ & $\begin{array}{l}\text { No. of } \\
\text { unique } \\
\text { firms }\end{array}$ & Mean & Std.dev. & 25 th & Median & 75 th \\
\hline Inetsales & 32,326 & 7135 & 6.0513 & 6.0302 & 0 & 7.6014 & 11.9184 \\
\hline laglnetsales & 32,326 & 7135 & 5.5796 & 6.0249 & 0 & 0 & 11.7166 \\
\hline $\begin{array}{l}\text { llaglnet- } \\
\text { sales }\end{array}$ & 32,326 & 7135 & 5.0925 & 5.9900 & 0 & 0 & 11.5090 \\
\hline $\begin{array}{l}\text { lllaglnet- } \\
\text { sales }\end{array}$ & 32,326 & 7135 & 4.6237 & 5.9120 & 0 & 0 & 11.2077 \\
\hline crashrisk & 32,326 & 7135 & 0.1791 & 0.3834 & 0 & 0 & 0 \\
\hline ncskew & 32,326 & 7135 & -5.1003 & 18.1146 & -12.3201 & -4.4734 & 3.0900 \\
\hline duvol & 32,326 & 7135 & -0.1773 & 0.4339 & -0.4119 & -0.1523 & 0.0849 \\
\hline changeroa & 32,326 & 7135 & -0.0214 & 1.3579 & -0.0314 & -0.0011 & 0.0203 \\
\hline roa & 32,326 & 7135 & 0.0256 & 1.9649 & -0.0049 & 0.0357 & 0.0734 \\
\hline retvol & 32,326 & 7135 & 0.1305 & 0.0979 & 0.0725 & 0.1065 & 0.1571 \\
\hline $\begin{array}{l}\text { sales }_{-} \\
\text {growth }\end{array}$ & 32,326 & 7135 & 0.6130 & 66.2252 & -0.0454 & 0.0675 & 0.2051 \\
\hline optiong & 32,326 & 7135 & 2.5428 & 8.0249 & 0 & 0 & 1.3 \\
\hline size & 32,326 & 7135 & 6.0937 & 2.0959 & 4.6585 & 6.1764 & 7.4993 \\
\hline btm & 32,326 & 7135 & 0.9334 & 5.9271 & 0.3153 & 0.5442 & 0.9038 \\
\hline ret & 32,326 & 7135 & 0.0148 & 0.6886 & -0.2998 & -0.0597 & 0.1897 \\
\hline tradvol & 32,326 & 7135 & 1.3851 & 1.4487 & 0.4066 & 0.8935 & 1.8417 \\
\hline leadret & 32,326 & 7135 & -0.0045 & 0.7120 & -0.3282 & -0.0689 & 0.1876 \\
\hline leadtradvol & 32,326 & 7135 & 1.4281 & 1.7546 & 0.4157 & 0.9036 & 1.8464 \\
\hline anacov & 32,326 & 7135 & 31.8642 & 43.0978 & 1 & 17 & 44 \\
\hline$h p$ & 32,326 & 7135 & -1004.1310 & 1181.3660 & -1554.8140 & -418.0119 & -104.5542 \\
\hline$k z$ & 23,479 & 5932 & 1.0763 & 11.2736 & 0.4347 & 0.8256 & 1.2595 \\
\hline$w w$ & 32,326 & 7135 & -0.2357 & 2.3346 & -0.2887 & -0.2198 & -0.1506 \\
\hline payout & 11,074 & 3201 & 0.0796 & 27.4089 & 0 & 0.1448 & 0.4080 \\
\hline stdearnings & 32,326 & 7135 & 94.1098 & 943.2668 & 3.4301 & 11.2160 & 40.7433 \\
\hline opacity & 23,208 & 5680 & 18.7112 & 336.6337 & 0.0525 & 0.1313 & 0.4598 \\
\hline dedi & 32,326 & 7135 & 0.0581 & 0.0846 & 0 & 0.0242 & 0.0920 \\
\hline sox & 32,326 & 7135 & 0.5420 & 0.4982 & 0 & 1 & 1 \\
\hline
\end{tabular}

This table tabulates the descriptive statistics of all the variables used for the hypothesis tests. The sample period ranges from 1993 to 2013. All the variables are defined in the "Appendix"

\subsection{Measures of insider sales}

Insiders are subject to an established legal jeopardy for selling immediately (e.g., within one quarter or less) before price-relevant events (e.g., Garfinkel 1997; Noe 1999; Huddart et al. 2007). Thus, we measure insider selling in a way such that its measurement window ends three months prior to the beginning of the year for which the crash risk variable (crashrisk) is measured. In particular, our insider sales variable (Inetsales) equals the natural logarithm of 1 plus the volume amount of net insider sales (i.e., insider sales minus insider purchases) made by all a firm's directors and officers over a year ending three 
(a) The association between insider sales and 15-month-ahead crash risk

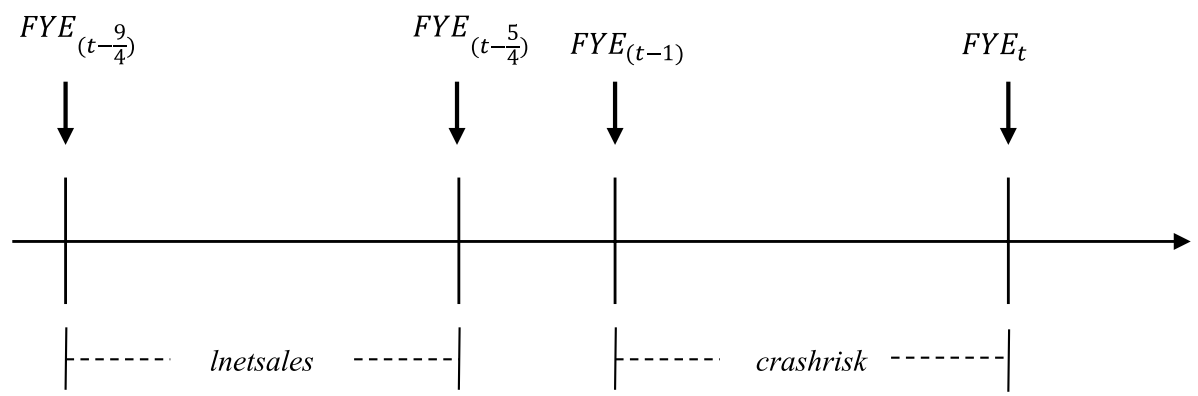

(b) The association between insider sales and 27-month-ahead crash risk

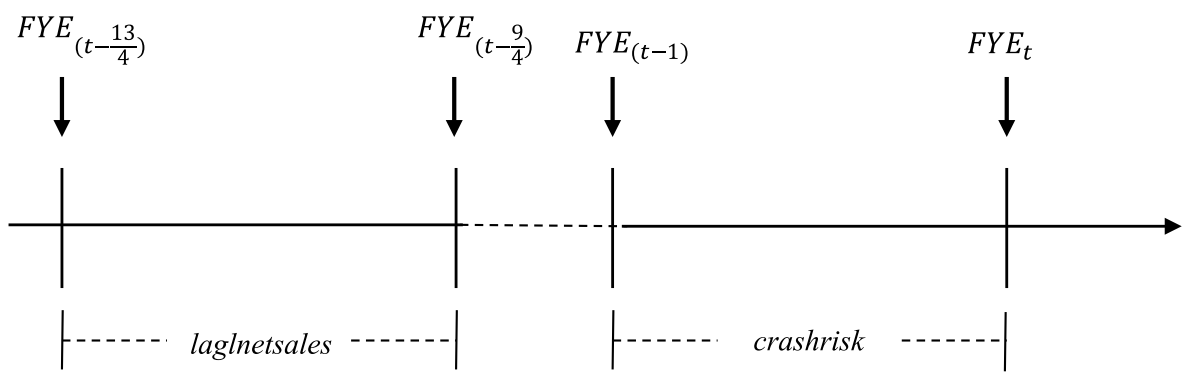

Fig. 1 Timeline for the measures of insider sales and crash risk. a The association between insider sales and 15-month-ahead crash risk. Notes: a shows the timeline for measurements of the dependent variable (i.e., lnetsales) and the key independent variable (i.e., crashrisk) that are used for the multivariate tests of the hypotheses $\mathrm{H} 1-\mathrm{H} 4$. Both the crash risk variable and insider selling variable are defined in the "Appendix". b The association between insider sales and 27-month-ahead crash risk. Notes: b shows the timeline for measurements of the dependent variable (i.e., laglnetsales) and the key independent variable (i.e., crashrisk) that are used for the test of the association between insider sales and 27-month-ahead crash risk. Both the crash risk variable and insider selling variable are defined in the "Appendix"

months prior to the beginning of the year for which the crash risk variables are measured, and equals 0 if the volume amount of net insider sales is negative. ${ }^{10}$ Part (a) of Fig. 1 portrays the timeline for the crash risk and insider selling variables' measurement windows. This shows how lnetsales is measured over the 12-month period $(\mathrm{t}-9 / 4, \mathrm{t}-5 / 4)$ ending one quarter before the crashrisk estimation period $(\mathrm{t}-1, \mathrm{t})$, where $\mathrm{t}$ denotes the end of the crash risk fiscal year. ${ }^{11}$

\footnotetext{
10 We get even stronger results in support of our hypotheses if we re-define the insider sales variable in a way that it is added with a negative sign when the volume amount of net insider sales is negative. All our results also hold if we use the dollar amount of net insider sales, or the volume or dollar amount of raw insider sales, to construct our insider selling variables.

11 We do not separate routine insider trades from non-routine insider trades in our analysis. This is because in an attempt to make their trades appear non-opportunistic and "uninformed" to outside investors, insiders may engage in routine trades, instead of non-routine trades, to reduce detection risk and potential reputa-
} 


\section{Research methodology}

\subsection{Multivariate test of the hypothesis $\mathrm{H} 1$}

To test the hypothesis H1, we employ the following pooled OLS regression model:

$$
\begin{aligned}
\text { Inetsales }= & \alpha_{0}+\alpha_{1} \text { crashrisk }+\alpha_{2} \text { changeroa }+\alpha_{3} \text { roa }+\alpha_{4} \text { retvol }+\alpha_{5} \text { salesgrowth } \\
& +\alpha_{6} \text { optiong }+\alpha_{7} \text { size }+\alpha_{8} \text { btm }+\alpha_{9} \text { qtrret }+\alpha_{10} \text { tradevol }+\alpha_{11} \text { leadqtrret } \\
& +\alpha_{12} \text { leadtradevol }+\alpha_{13} \text { anacov }+\alpha_{14} \text { laglnetsales }+\alpha_{15} \text { stdearnings }+\alpha_{16} w w \\
& +\alpha_{17} \text { dedi }+\alpha_{18} \text { SOX }+\alpha_{19} \text { year-fixedeffects }+\alpha_{20} \text { industry-fixedeffects }+\varepsilon
\end{aligned}
$$

The theme of the hypothesis test is to look at whether insiders' anticipation of future crash risk motivates them to sell down their stocks in advance. The causality flow runs from future crash risk to insider sales. Thus, the dependent variable is lnetsales and the key independent variable is crashrisk, both of which are as defined previously. Prior studies that examine information-driven insider sales conduct multivariate analyses, in which the dependent variable is insider sales, and the key independent variable is future bad news events which proxy for insiders' foreknowledge of future bad news events (e.g., Ke et al. 2003; Piotroski and Roulstone 2005; Agrawal and Cooper 2015; Dechow et al. 2016). Our regression model specification is akin to those used in these studies. In a similar way to prior research, we use future crash risk to proxy for insiders' anticipation of future crash risk and as our key explanatory variable for insider sales.

Insiders trading immediately (e.g., within one quarter or shorter) before price-relevant corporate events violate insider trading laws directly, and will trigger exceptionally high litigation risk (e.g., Garfinkel 1997; Huddart et al. 2007), compared with trading a longer time in advance. Therefore, in our main tests, we allow a 3-month interval between the measurement window of insider selling and that of crash risk. ${ }^{12}$ As such, on average, crash risk is measured 15 months ahead of insider sales. Based on the hypothesis H1, the coefficient on crashrisk should be positive and statistically significant at a conventional level.

We include a broad set of control variables in the regression to mitigate potential correlated- omitted-variable(s) bias. As discussed in Sect. 2, information asymmetry between insiders and outsiders likely induces more insider sales, whilst financial constraints and the implementation of SOX likely reduce insider sales. Therefore, we control for information asymmetry (stdearnings), financial constraints $(w w)$, and SOX (sox) in our regression model. Earnings volatility (stdearnings) is used as the proxy for information asymmetry, and is expected to be positively correlated with insider sales. For our measure of financial constraints, we employ Whited and Wu's (2006) WW index. A high value of the WW index $(w w)$ represents a high degree of financial constraints, and hence should be associated with reduced insider sales.

Because high stock return volatility provides insiders with more room to exploit their information advantage and to profit from their stock trades, we control for stock return

\footnotetext{
Footnote 11 (continued)
}

tional and legal costs associated with informed insider sales (e.g., Amel-Zedeh et al. 2019; He and Marginson 2020).

12 All the inferences for the tests of the hypotheses H1-H4 remain unchanged if we remove the threemonth interval. 
volatility (retvol), and expect it to be positively related to insider sales. Strong external monitoring restrains opportunistic informed trades. Hence, we control for analyst coverage (anacov) and dedicated institutional stock ownership (dedi). Higher analyst coverage and higher dedicated institutional ownership are likely to be associated with more intensive external monitoring (e.g., Chen et al. 2015, 2007; He et al. 2019) and thus with less informed insider sales. We control for firm size (size) because insiders in large firms trade their stocks more actively (Lakonishok and Lee 2001). We also include the number of option grants (optiong), as Ofek and Yermack (2000) find that insiders sell more shares when granted more stock options. We include sales growth (salesgrowth) since Rozeff and Zaman (1998) find that insiders in growth firms sell down more of their stocks. Piotroski and Roulstone (2005) find that insider trades are positively related to future earnings performance (a proxy for insiders' superior knowledge about future cash flow realizations), positively associated with book-to-market ratio, and negatively related to recent returns (proxies for insiders' contrarian beliefs). Hence, we control for return on assets (roa), change in return on assets (changeroa), book-to-market ratio ( $\mathrm{btm}$ ), and buy-and-hold stock returns (ret). We include these variables also because they capture firm performance and future prospect that are likely to be correlated with both insider sales and future crash risk.

High trading volume is associated with a large difference in opinions among investors (Chen et al. 2001) and hence with a higher likelihood of stock mispricing. Since insiders have incentives to trade against mispricing, trading volume should be positively associated with insider trades. High trading volume is also associated with stock liquidity. The more liquid the stocks, the easier it is for insiders to dispose of their shares. We therefore include trading volume (tradevol) in our regression model and expect tradevol to be positively related to insider sales. The inclusion of ret and tradevol in the regression also reduces any potential correlated-omitted-variable(s) bias induced by events (e.g., M\&A) that influence firm fundamentals. ret and tradevol are measured in the same window as that of lnetsales, while the other foregoing control variables are measured in a one-year window that ends at the beginning of the measurement window for our crash risk variables. Following Cheng and Lo (2006), we also include lagged insider sales (laglnetsales) to further control for unobserved factors that might be driving insider sales. As suggested by prior literature, insiders are inclined to trade on various bad news events. To control for this possibility, we further include in our regression future stock returns (leadret) and future trading volume (leadtradevol), which are measured in the same window as that of our crash risk variables. All the control variables are defined in the "Appendix". Last, we include industry- and year-fixed effects in our regression model to control for any systematic variation in insider sales across industries and years.

\subsection{Tests of the hypotheses H2-H4}

For ease of interpretation of the coefficients and to mitigate measurement problems, we adopt subsample analyses to test the hypotheses $\mathrm{H} 2-\mathrm{H} 4$. $\mathrm{H} 2$ relates to the effect of firm financial constraints on crash-risk-based insider sales. In testing this hypothesis, we employ four proxies for financial constraints: (1) the WW index developed by Whited and Wu (2006), (2) the HP index developed by Hadlock and Pierce (2010), (3) the KZ index developed by Kaplan and Zingales (1997), and (4) the dividend payout ratio used by Denis and Sibikov (2010). The WW index, HP index, and KZ index are coded in a way such that higher values represent greater financial constraints. The dividend payout ratio runs in the opposite direction: higher dividend payout indicates lower financial constraints (Fazzari 
et al. 1988). Detailed definitions of these variables are given in the "Appendix". We partition our full sample into two subsamples based on the sample medians of the WW index, $\mathrm{HP}$ index, and KZ index, respectively, and on an indicator variable for whether a firm has a dividend payout in the fiscal year. Then we estimate Model (1) separately for the two subsamples that are formed based on the four financial constraint indicators, respectively. If the hypothesis $\mathrm{H} 2 \mathrm{a}(\mathrm{H} 2 \mathrm{~b})$ holds, the coefficient on crashrisk should be less (more) positive for the high-financial-constraint subsample than for the low-financial-constraint subsample.

The hypothesis H3 is concerned with whether information asymmetry between insiders and outsiders moderates the relationship between insider sales and future crash risk. To test this hypothesis, we first split our full sample into two subsamples based on the sample medians of the measures of information asymmetry. Financial opacity (opacity) is used as the proxy for information asymmetry and is measured as per Hutton et al. (2009). High financial opacity indicates high information asymmetry. We estimate Model (1) separately for the two subsamples. The hypothesis $\mathrm{H} 3$ predicts that the coefficient on crashrisk for the high-information-asymmetry subsample is more positive than that for the low-informationasymmetry subsample.

Finally, the hypothesis H4 explores whether SOX has a moderating effect on the relationship between insider sales and future crash risk. To test this hypothesis, we divide our full sample into two subsamples based on an indicator variable for whether a firm is in the pre- or post-SOX period, and then run Model (1) separately for these two subsamples. ${ }^{13}$ If the hypothesis $\mathrm{H} 4$ is supported, crashrisk should have a more positive coefficient for the pre-SOX subsample than for the post-SOX subsample.

\subsection{Accounting for endogeneity}

Insider trading, by itself, helps push stock prices towards fundamental value (Piotroski and Roulstone 2005), thus reverse causality might arise in the way that insider sales reduce stock price crash risk. However, this potential reverse causality relates to a negative, contemporaneous association between insider sales and crash risk, which is unlikely to explain the positive, lead-lag association between insider sales and crash risk, as predicted in the hypothesis H1. In particular, firm-specific stock price crashes are, fundamentally, triggered by a "burst-out" of accumulated withheld bad news (Jin and Myers 2006; Hutton et al. 2009; He 2015). If managers withhold and accumulate bad news, the extent to which their stocks are overpriced will increase, with a consequential increase in stock price crash risk. If, on the contrary, managers release bad news when known, stock prices will move towards fundamental value on a timely basis, such that the degree of overpricing will be abated, and crash risk will fall. In a similar way, insider sales will move stock prices towards intrinsic value, thereby mitigating crash risk as well. Whereas a stock price crash might, occasionally, follow insider sales, in such a case, it would be the actual insider sales driving the stock price down towards fundamental value in the cross-section; as such, the likelihood of any future stock price crash will be reduced. Most importantly, our main results concern insider sales that are made on an average of 15-month-ahead crash risk, and hence are

\footnotetext{
13 In testing the hypothesis H4, we exclude the financial crisis period 2007-2009 (e.g., Jaggi et al. 2010; Acharya et al. 2009; Adrian and Shin 2010) to eliminate the potential confounding effects of the crisis on crash-risk-based insider sales in the post-SOX sample period.
} 
unlikely to be driven by any potential reverse causality which runs in the opposite direction to our prediction in the hypothesis $\mathrm{H} 1$.

Another possible explanation for the hypothesis $\mathrm{H} 1$ is that, in order to profit from insider sales, managers might withhold bad news to achieve a higher stock price before insider sales, which increases the probability of a stock price crash. Nevertheless, managers only have the incentive to withhold bad news before their insider-sales transactions, and will no longer have such an incentive after they have sold down their stocks. For this reason, managerial incentives for insider selling cannot be used to proxy for actual insider sales in our study which is concerned with insider sales made on a relatively long horizon (i.e., 15-month-ahead on average), hence the alternative explanation is unlikely to hold. That said, to further alleviate potential endogeneity issues, we do an analysis of the impact threshold for a confounding variable method per Larcker and Rusticus (2010), and conduct a falsification test. Results are discussed in the next section.

\section{Empirical results}

\subsection{Results for the hypotheses H1-H4}

Table 2 reports the regression results for the test of the association between insider sales and future stock price crash risk. The coefficient on crashrisk is positive and statistically significant at the $1 \%$ level. A one-unit change in crashrisk leads to a change of 0.1783 in lnetsales, which accounts for around $3 \%$ of its mean value for our sample. This result supports the hypothesis $\mathrm{H} 1$-insider sales are positively correlated with future crash risk. This suggests that insiders are able to assess the likelihood of the future stock price crash that results from bad news hoarding, and this motivates insiders to sell their stocks in anticipation of high future crash risk. We check the robustness of our baseline regression results using our alternative measures of crash risk, ncskew and duvol, which are described earlier in Sect. 3.2. Results are reported in Columns (2) and (3), and our inferences remain unchanged. Most control variables have statistically significant coefficients with the expected signs.

Table 3 reports the regression results for Model (1) estimated separately for our two subsamples comprising firms with high versus low financial constraints. The crashrisk coefficient is positive and statistically significant across all the low-financial-constraint subsamples (which are represented by $d w w=0, d h p=0, d k z=0$, and dpayout $=1$, respectively). In contrast, the coefficient for crashrisk, albeit positive, is not statistically significant for the high-financial-constraint subsamples (represented by $d w w=1, d h p=1, d k z=1$, and dpayout $=0$, respectively). These results indicate that the positive association between insider selling and future crash risk is evident only for firms that are in the low-financialconstraint subsample, thus lending support to the hypothesis $\mathrm{H} 2 \mathrm{a}$.

Table 4 presents the regression results for Model (1) run separately for the subsample firms with high versus low information asymmetry between insiders and outsiders. dopacity $=1$ (0) represents the high- (low-) information-asymmetry subsample with above(below-) median value of opacity, respectively. crashrisk has a highly significant, positive coefficient in the high-opacity (dopacity $=1)$ subsample but a statistically insignificant coefficient $(p=0.796)$ in the low-opacity (dopacity $=0)$ subsample. These results suggest that the positive link between insider sales and future crash risk is more evident for firms that have high information asymmetry, thus consistent with the hypothesis $\mathrm{H} 3$. 
Table 2 Test of H1: the association between insider sales and future stock price crash risk

\begin{tabular}{|c|c|c|c|c|}
\hline \multirow[t]{2}{*}{ Variables } & \multirow[t]{2}{*}{ Pred. Sign } & \multicolumn{3}{|c|}{ Dependent variable $=$ lnetsales } \\
\hline & & (1) & (2) & (3) \\
\hline \multirow[t]{2}{*}{ Intercept } & ? & 0.2553 & $0.3555^{*}$ & $0.4217 * *$ \\
\hline & & $(0.217)$ & $(0.088)$ & $(0.045)$ \\
\hline \multirow[t]{2}{*}{ crashrisk } & + & $0.1783 * *$ & & \\
\hline & & $(0.012)$ & & \\
\hline \multirow[t]{2}{*}{ ncskew } & + & & $0.0052 * * *$ & \\
\hline & & & $(<0.001)$ & \\
\hline \multirow[t]{2}{*}{ duvol } & + & & & $0.2874 * * *$ \\
\hline & & & & $(<0.001)$ \\
\hline \multirow[t]{2}{*}{ changeroa } & - & -0.0196 & -0.0197 & $-0.0215^{*}$ \\
\hline & & $(0.106)$ & $(0.102)$ & $(0.078)$ \\
\hline \multirow[t]{2}{*}{ roa } & - & $-0.0183^{* *}$ & $-0.0183^{* *}$ & $-0.0192 * * *$ \\
\hline & & $(0.019)$ & $(0.019)$ & $(0.010)$ \\
\hline \multirow[t]{2}{*}{ retvol } & + & $-1.1809^{* * *}$ & $-1.2120^{* * *}$ & $-1.0538 * * *$ \\
\hline & & $(0.001)$ & $(0.001)$ & $(0.003)$ \\
\hline \multirow[t]{2}{*}{ salesgrowth } & + & 0.0118 & 0.0118 & 0.0119 \\
\hline & & $(0.168)$ & $(0.167)$ & $(0.167)$ \\
\hline \multirow[t]{2}{*}{ optiong } & + & $0.0213 * * *$ & $0.0216^{* * *}$ & $0.0216 * * *$ \\
\hline & & $(0.001)$ & $(0.001)$ & $(0.001)$ \\
\hline \multirow[t]{2}{*}{ size } & + & $0.4465 * * *$ & $0.4402 * * *$ & $0.4301 * * *$ \\
\hline & & $(<0.001)$ & $(<0.001)$ & $(<0.001)$ \\
\hline \multirow[t]{2}{*}{$b t m$} & + & -0.0009 & -0.0008 & -0.0010 \\
\hline & & $(0.784)$ & $(0.821)$ & $(0.780)$ \\
\hline \multirow[t]{2}{*}{ ret } & - & $0.8955^{* * *}$ & $0.8955^{* * *}$ & $0.8892 * * *$ \\
\hline & & $(<0.001)$ & $(<0.001)$ & $(<0.001)$ \\
\hline \multirow[t]{2}{*}{ tradevol } & + & $0.2653 * * *$ & $0.2653 * * *$ & $0.2620 * * *$ \\
\hline & & $(<0.001)$ & $(<0.001)$ & $(<0.001)$ \\
\hline \multirow[t]{2}{*}{ leadret } & - & -0.0472 & -0.0455 & -0.0297 \\
\hline & & $(0.192)$ & $(0.207)$ & $(0.415)$ \\
\hline \multirow[t]{2}{*}{ leadtradevol } & + & $0.0412 *$ & $0.0430 *$ & $0.0468 * *$ \\
\hline & & $(0.081)$ & $(0.068)$ & $(0.048)$ \\
\hline \multirow[t]{2}{*}{ anacov } & - & $0.0041 * * *$ & $0.0040 * * *$ & $0.0042 * * *$ \\
\hline & & $(<0.001)$ & $(<0.001)$ & $(<0.001)$ \\
\hline \multirow[t]{2}{*}{ laglnetsales } & + & $0.4710^{* * *}$ & $0.4710^{* * *}$ & $0.4710 * * *$ \\
\hline & & $(<0.001)$ & $(<0.001)$ & $(<0.001)$ \\
\hline \multirow[t]{2}{*}{ stdearnings } & + & $-0.0001 *$ & $-0.0001 *$ & $-0.0001 *$ \\
\hline & & $(0.094)$ & $(0.094)$ & $(0.098)$ \\
\hline \multirow[t]{2}{*}{$w w$} & - & 0.3452 & 0.3449 & 0.3462 \\
\hline & & $(0.160)$ & $(0.159)$ & $(0.160)$ \\
\hline \multirow[t]{2}{*}{ dedi } & - & $3.3248 * * *$ & $3.3284 * * *$ & $3.3109 * * *$ \\
\hline & & $(<0.001)$ & $(<0.001)$ & $(<0.001)$ \\
\hline \multirow[t]{2}{*}{ sox } & - & -0.2599 & -0.2589 & -0.2690 \\
\hline & & $(0.285)$ & $(0.286)$ & $(0.268)$ \\
\hline Year-fixed effects & & Included & Included & Included \\
\hline
\end{tabular}


Table 2 (continued)

\begin{tabular}{|c|c|c|c|c|}
\hline \multirow[t]{2}{*}{ Variables } & \multirow[t]{2}{*}{ Pred. Sign } & \multicolumn{3}{|c|}{ Dependent variable $=$ lnetsales } \\
\hline & & (1) & (2) & (3) \\
\hline Industry-fixed effects & & Included & Included & Included \\
\hline R-squared & & 0.4088 & 0.4089 & 0.4090 \\
\hline Num. of observations & & 32,326 & 32,326 & 32,326 \\
\hline
\end{tabular}

This table reports the OLS regression results for the tests of the association between insider sales and future stock price crash risk. The sample period covers the years 1993-2013. The dependent variable is lnetsales. The key independent variables are crashrisk, ncskew, and duvol, three distinct proxies for stock price crash risk. All the variables in the table are defined in the "Appendix". Year- and industry-fixed effects are included in the regressions but not reported for simplicity. The industry-fixed effects are based on the industry dummies constructed from the first two digits of SIC codes. The $p$ values in parentheses are based on robust standard errors clustered by firm. $* * *, * *$, *represent the $1 \%, 5 \%$, and $10 \%$ statistical significance levels (two-tailed), respectively

Table 5 reports the regression results for the test of the hypothesis H4. Subsamples are formed based on whether firms are in the post-SOX or in the pre-SOX period. The coefficient for crashrisk in the pre-SOX $($ sox $=0)$ subsample is positive and statistically significant $(p=0.035)$, whereas the coefficient for crashrisk in the post-SOX $($ sox $=1)$ subsample is only marginally significant $(p=0.073) .{ }^{14}$ This finding suggests that insider sales are more strongly, positively associated with future crash risk before the implementation of SOX, and is also consistent with Hutton et al. (2009) who find that the positive association between financial opacity and future crash risk subsides in the post-SOX era.

\subsection{Results for coping with potential endogeneity}

In all the multivariate tests that we have conducted thus far, we control not only for an extensive set of variables that are potentially correlated with both insider sales and future crash risk, but also for industry-fixed effects. But we cannot completely exclude the possibility that our regression analysis still omits some variable(s) that might drive both insider sales and crash risk. To address this concern, we follow Larcker and Rusticus (2010) to conduct the Impact Threshold for a Confounding Variable (ITCV) test. Bias induced by an omitted variable is determined by its correlations with the key independent variable and with the dependent variable, and can be appraised by the impact threshold for a confounding variable (ITCV). The ITCV is defined as the minimum value of the product of two correlations (i.e., the partial correlation between the dependent variable and the confounding variable, and the partial correlation between the key independent variable and the confounding variable) that would cause the observed statistical relation between the key independent variable and the dependent variable to become statistically insignificant at the 5\% level. Using the ITCV, we can gauge how strong the confounding effect would have to be to invalidate our results and inferences should an omitted variable have been controlled in the regression model (Frank 2000). The larger the value of ITCV, the less susceptible our

\footnotetext{
14 Option grant data in Compustat are missing for almost all firm-year observations for the years before the passage of SOX. Hence, we do not include the optiong variable in the multivariate test of the hypothesis H4.
} 


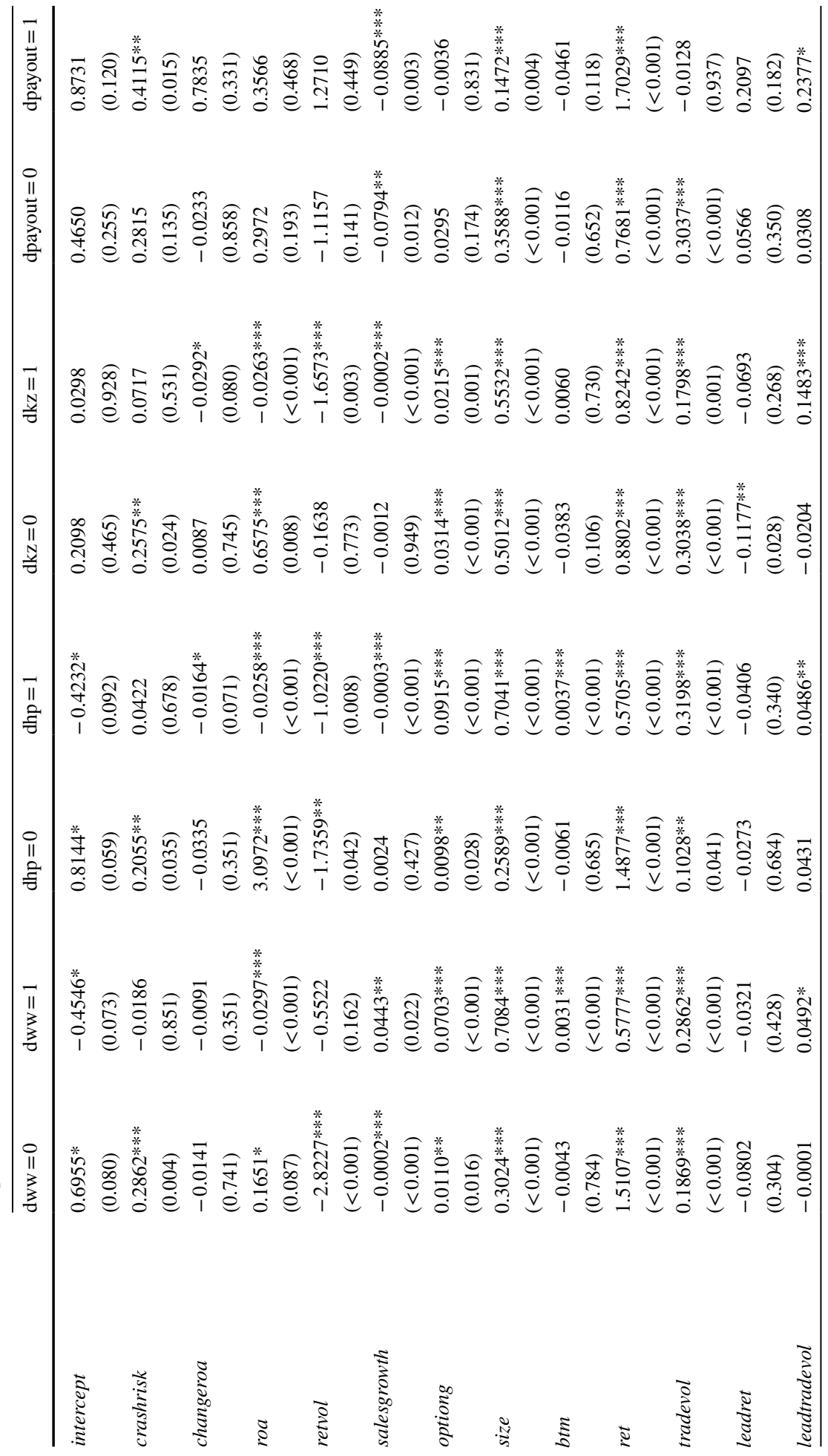




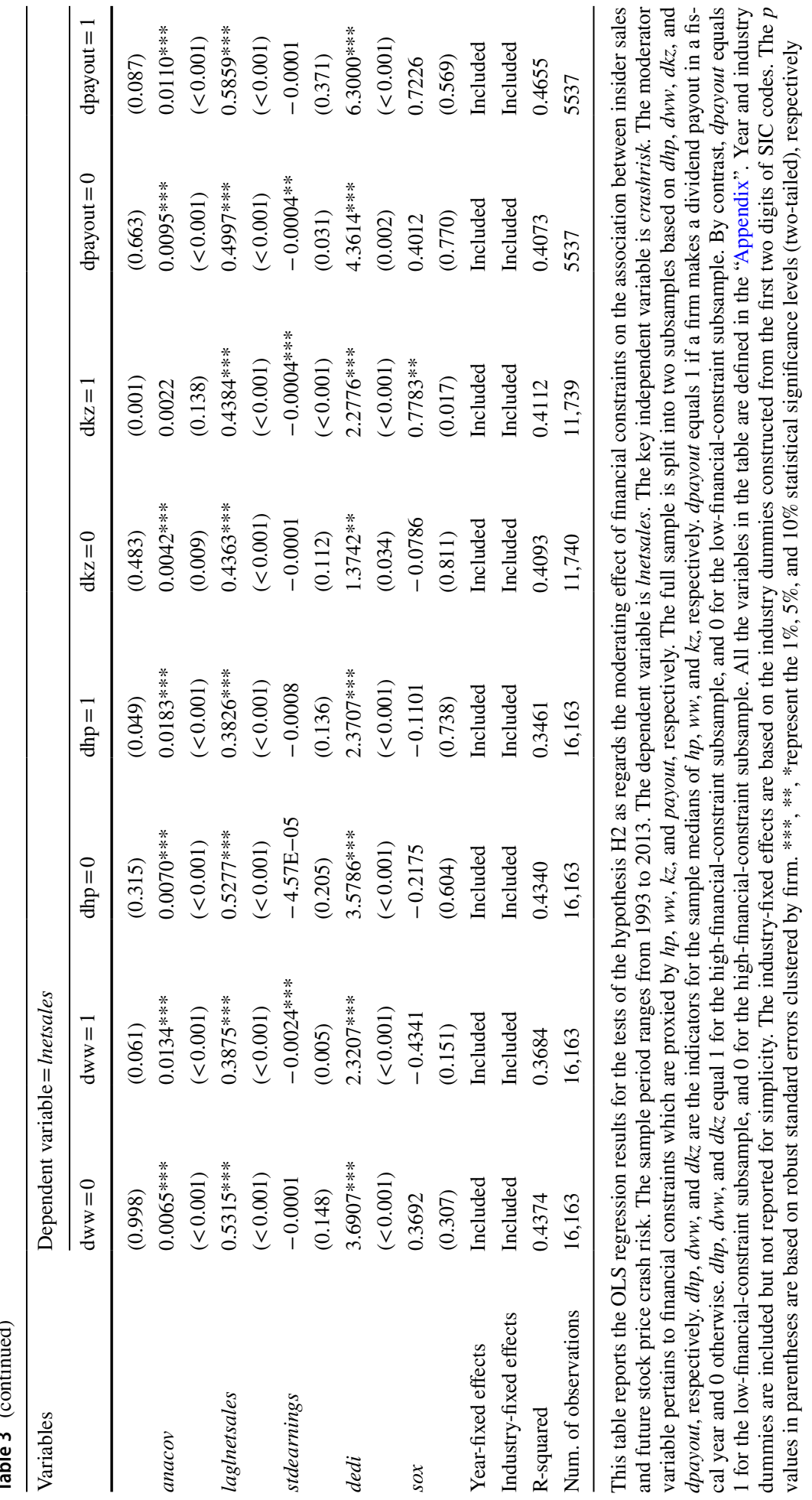


Table 4 Test of H3: the moderating effect of information asymmetry

\begin{tabular}{|c|c|c|}
\hline \multirow[t]{2}{*}{ Variables } & \multicolumn{2}{|c|}{ Dependent variable $=$ lnetsales } \\
\hline & dopacity $=0$ & dopacity $=1$ \\
\hline Intercept & $\begin{array}{l}0.9252^{* *} \\
(0.021)\end{array}$ & $\begin{array}{l}-0.7530^{* *} \\
(0.015)\end{array}$ \\
\hline crashrisk & $\begin{array}{l}0.0320 \\
(0.796)\end{array}$ & $\begin{array}{l}0.3332 * * * \\
(0.003)\end{array}$ \\
\hline changeroa & $\begin{array}{l}0.0086 \\
(0.719)\end{array}$ & $\begin{array}{l}-0.0127 \\
(0.225)\end{array}$ \\
\hline roa & $\begin{array}{l}0.1661 * * * \\
(0.001)\end{array}$ & $\begin{array}{l}-0.0325 * * * \\
(<0.001)\end{array}$ \\
\hline retvol & $\begin{array}{l}-1.8936^{* * *} \\
(0.007)\end{array}$ & $\begin{array}{l}-1.1386^{* *} \\
(0.021)\end{array}$ \\
\hline salesgrowth & $\begin{array}{l}0.0801 \\
(0.126)\end{array}$ & $\begin{array}{l}0.1439 * * * \\
(<0.001)\end{array}$ \\
\hline optiong & $\begin{array}{l}0.0330^{* * *} \\
(0.001)\end{array}$ & $\begin{array}{l}0.0165^{*} \\
(0.068)\end{array}$ \\
\hline size & $\begin{array}{l}0.4392 * * * \\
(<0.001)\end{array}$ & $\begin{array}{l}0.6849 * * * \\
(<0.001)\end{array}$ \\
\hline btm & $\begin{array}{l}0.0025^{*} \\
(0.070)\end{array}$ & $\begin{array}{l}-0.0108 \\
(0.311)\end{array}$ \\
\hline ret & $\begin{array}{l}1.1067 * * * \\
(<0.001)\end{array}$ & $\begin{array}{l}0.6120^{* * *} \\
(<0.001)\end{array}$ \\
\hline tradevol & $\begin{array}{l}0.2388^{* * *} \\
(<0.001)\end{array}$ & $\begin{array}{l}0.2717 * * * \\
(<0.001)\end{array}$ \\
\hline leadret & $\begin{array}{l}0.0260 \\
(0.729)\end{array}$ & $\begin{array}{l}-0.0197 \\
(0.702)\end{array}$ \\
\hline leadtradevol & $\begin{array}{l}0.0060 \\
(0.917)\end{array}$ & $\begin{array}{l}0.0657^{* *} \\
(0.026)\end{array}$ \\
\hline anacov & $\begin{array}{l}0.0069 * * * \\
(<0.001)\end{array}$ & $\begin{array}{l}0.0032^{* *} \\
(0.034)\end{array}$ \\
\hline laglnetsales & $\begin{array}{l}0.4906 * * * \\
(<0.001)\end{array}$ & $\begin{array}{l}0.4500^{* * *} \\
(<0.001)\end{array}$ \\
\hline stdearnings & $\begin{array}{l}-0.0001 * * * \\
(0.002)\end{array}$ & $\begin{array}{l}-0.0001 \\
(0.198)\end{array}$ \\
\hline$w w$ & $\begin{array}{l}3.1971 \text { ** } \\
(0.038)\end{array}$ & $\begin{array}{l}4.1194 * * * \\
(<0.001)\end{array}$ \\
\hline dedi & $\begin{array}{l}4.1739 * * * \\
(<0.001)\end{array}$ & $\begin{array}{l}4.0897 * * * \\
(<0.001)\end{array}$ \\
\hline $\operatorname{sox}$ & $\begin{array}{l}0.8249^{*} \\
(0.078)\end{array}$ & $\begin{array}{l}0.4590 \\
(0.215)\end{array}$ \\
\hline Year-fixed effects & Included & Included \\
\hline Industry-fixed effects & Included & Included \\
\hline R-squared & 0.4091 & 0.4183 \\
\hline Num. of observations & 11,604 & 11,604 \\
\hline
\end{tabular}


Table 4 (continued)

This table reports the OLS regression results for the tests of the hypothesis $\mathrm{H} 3$ as regards the moderating effect of information asymmetry on the association between insider sales and future crash risk. The sample period ranges from 1993 to 2013. The dependent variable is lnetsales. The key independent variable is crashrisk. The moderator variable pertains to information asymmetry which is proxied by opacity. The full sample is split into two subsamples separated by dopacity, a binary variable constructed based on the sample median of opacity. All the variables in the table are defined in the "Appendix". Year and industry dummies are included but not reported for brevity. The industry-fixed effects are based on the industry dummies constructed from the first two digits of SIC codes. The $p$ values in brackets are based on robust standard errors clustered by firm. ***, **, *represent the $1 \%$, $5 \%$, and $10 \%$ statistical significance levels (two-tailed), respectively

regression results are to potential omitted-variable(s) bias. Table 6 reports the results of our ITCV test. The ITCV is estimated to be 0.0075 , which is higher than the absolute value of the impact factor (Impact) of all the control variables (except the lagged dependent variable, laglnetsales) used in Model (1). This result provides assurance that our findings relating to our main hypothesis $\mathrm{H} 1$ are robust to the potential correlated-omitted-variable(s) problem.

To lend more credence to our baseline regression results, we also conduct a placebo test. Specifically, we look at stock trades made by non-officer employees who are unlikely to affect major corporate decisions. If any correlated omitted variable, or reverse causality, were driving our main results, we should find a significant association between non-officer employees' stock sales and future stock price crash risk. However, as shown in Table 7, we fail to find any such result, thereby rendering it unlikely that our main results are driven by omitted variables or reverse causality.

\section{Additional analysis}

In our main tests, we link insider sales with future crash risk on a 15-month-ahead horizon. In this section, we conduct longer-horizon tests of the hypothesis $\mathrm{H} 1$ by moving the measurement window of future crash risk beyond 15 months. Specifically, we link insider sales to 27 -month-ahead crash risk. ${ }^{15}$ Part (b) of Fig. 1 presents the timeline for our measurement windows of insider sales and of 27 -month-ahead crash risk. ${ }^{16}$ We replace lnetsales with laglnetsales on the left-hand side of Model (1), substitute laglnetsales for llaglnetsales on the right-hand side of the equation, and re-run the regression model.

Table 8 reports the regression results. The coefficient on crashrisk has the predicted positive sign but is statistically significant only at the $10 \%$ level $(p=0.083)$. A one-unit increase in crashrisk leads to an increase of 0.1397 in laglnetsales, which is equivalent to approximately $2.2 \%$ of its mean value in our sample. Collectively, we find relatively weaker evidence on insider sales that are made based on 27-month-ahead crash risk than

\footnotetext{
15 In parallel with footnote 12 , we also find evidence (results not tabulated for brevity) that insider sales are positively associated with 2-year-ahead stock price crash risk.

${ }^{16}$ In un-tabulated tests, we expand our measurement window of future crash risk from 1-year duration to 2-year, which commences 3 months after the end of the measurement window for insider sales. Our inferences remain similar for using this alternative measure of future crash risk.
} 
Table 5 Test of H4: the moderating effect of the Sarbanes-Oxley Act of 2002

\begin{tabular}{|c|c|c|}
\hline \multirow[t]{2}{*}{ Variables } & \multicolumn{2}{|c|}{ Dependent variable $=$ lnetsales } \\
\hline & $\operatorname{sox}=0$ & sox $=1$ \\
\hline \multirow[t]{2}{*}{ Intercept } & 0.0115 & $0.6841 * *$ \\
\hline & $(0.961)$ & $(0.021)$ \\
\hline \multirow[t]{2}{*}{ crashrisk } & $0.2337 * *$ & $0.1886^{*}$ \\
\hline & $(0.035)$ & $(0.073)$ \\
\hline \multirow[t]{2}{*}{ changeroa } & 0.0813 & -0.0505 \\
\hline & $(0.288)$ & $(0.106)$ \\
\hline \multirow[t]{2}{*}{ roa } & $0.2476^{*}$ & $-0.0278 * * *$ \\
\hline & $(0.069)$ & $(<0.001)$ \\
\hline \multirow[t]{2}{*}{ retvol } & 0.5132 & $-4.2329 * * *$ \\
\hline & $(0.301)$ & $(<0.001)$ \\
\hline \multirow[t]{2}{*}{ salesgrowth } & -0.0093 & 0.0358 \\
\hline & $(0.245)$ & $(0.110)$ \\
\hline \multirow[t]{2}{*}{ size } & $0.3121 * * *$ & $0.6185 * * *$ \\
\hline & $(<0.001)$ & $(<0.001)$ \\
\hline \multirow[t]{2}{*}{$b t m$} & -0.0021 & -0.0199 \\
\hline & $(0.462)$ & $(0.542)$ \\
\hline \multirow[t]{2}{*}{ ret } & $0.5745^{* * *}$ & $1.0681 * * *$ \\
\hline & $(<0.001)$ & $(<0.001)$ \\
\hline \multirow[t]{2}{*}{ tradevol } & $0.4471 * * *$ & $0.2981 * * *$ \\
\hline & $(<0.001)$ & $(<0.001)$ \\
\hline \multirow[t]{2}{*}{ leadret } & -0.0410 & -0.0389 \\
\hline & $(0.405)$ & $(0.627)$ \\
\hline \multirow[t]{2}{*}{ leadtradevol } & 0.0934 & $0.0839 * * *$ \\
\hline & $(0.114)$ & $(0.005)$ \\
\hline \multirow[t]{2}{*}{ anacov } & $0.0102 * * *$ & -0.0004 \\
\hline & $(<0.001)$ & $(0.789)$ \\
\hline \multirow[t]{2}{*}{ laglnetsales } & $0.4838 * * *$ & $0.4584 * * *$ \\
\hline & $(<0.001)$ & $(<0.001)$ \\
\hline \multirow[t]{2}{*}{ stdearnings } & $-2.37 \mathrm{E}-05$ & $-0.0001 * * *$ \\
\hline & $(0.287)$ & $(0.001)$ \\
\hline \multirow[t]{2}{*}{$w w$} & 0.1974 & $1.0062 *$ \\
\hline & $(0.195)$ & $(0.095)$ \\
\hline \multirow[t]{2}{*}{ dedi } & $6.0705^{* * *}$ & $1.1341 * *$ \\
\hline & $(<0.001)$ & $(0.041)$ \\
\hline Year-fixed effects & Included & Included \\
\hline Industry-fixed effects & Included & Included \\
\hline R-squared & 0.3530 & 0.4191 \\
\hline Num. of observations & 14,804 & 11,915 \\
\hline
\end{tabular}

This table reports the OLS regression results for the tests of the hypothesis $\mathrm{H} 4$ as to the moderating effect of Sarbanes-Oxley Act (SOX) on the association between insider sales and future stock price crash risk. The sample period ranges from 1993 to 2013, excluding the financial crisis period 2007-2009. The dependent variable is lnetsales. The key independent variable is crashrisk. The moderator variable is sox. The full sample is split into two subsamples based on sox. All the variables in the table are defined in the "Appendix". Year and industry dummies are included but not reported for brevity. The industry- 
Table 5 (continued)

$\overline{\text { fixed effects are based on the industry dummies constructed from the }}$ first two digits of SIC codes. The $p$ values in parentheses are based on robust standard errors clustered by firm. ***, **, *represent the $1 \%$, $5 \%$, and $10 \%$ statistical significance levels (two-tailed), respectively

on 15-month-ahead crash risk. This suggests that insiders are less able to forecast and trade on longer-term future crash risk. Such results and inferences are robust to running the ITCV and placebo tests covered in the previous section.

\section{Discussion and conclusion}

\subsection{Implications of our findings}

Crash-risk-based insider trades profit insiders at the expense of outside investors. This reinforces the need to deter such inequitable trades. As noted earlier, insider sales made based on future crash risk at a relatively long horizon are hard to see through and/or litigate against, not only because it is usually hard for investors to distinguish and authenticate information-driven sales from liquidity- or diversification-driven sales, but also because the extent of future crash risk is subject to considerable uncertainty. Therefore, it is difficult to inhibit such insider trading activities directly. However, they can be curbed indirectly. Theory (e.g., Glosten and Milgrom 1985; Kyle 1985; Huddart and Ke 2007) suggests that insider trades will be profitable to insiders only when information asymmetry exists between insiders and outsiders. In our case, if future stock price crash risk is assessed equally well by insiders vis-à-vis outsiders, insider trades based on future crash risk will be unprofitable to insiders and could thus be disincentivized. One way to put outsiders in an equal position to insiders in assessing future crash risk is to mandate managers to disclose their inside information in a complete, accurate, precise, and timely manner. Given the prevalence and significance of crash-risk-based insider sales as documented in our study, it is imperative for not only regulators but also firm shareholders to require managers to commit to full, timely, and accurate disclosures of corporate news to the market irrespective of the nature of the news.

\subsection{Concluding remarks}

This study examines whether managers sell their stocks based on future stock price crash risk. To our best knowledge, this paper is the first to address this issue directly in the literature. We find that insider sales are positively associated with future crash risk, which is consistent with insiders being able to assess future crash risk and to exploit this informational advantage for personal gain. We also find that the positive association between insider sales and future crash risk is more evident for firms that have high information opacity but less evident for firms that are financially constrained or in the post-SOX era. Our study sheds new light on crash-risk-based insider trades which circumvent extant legal disciplines, and offers insights on how such informed trades may plausibly be curbed in practice.

Acknowledgements We appreciate the helpful comments and suggestions from Cheng-Few Lee, the two anonymous reviewers, James Ohlson, Alok Kumar, Andrew Karolyi, John Leahy, April Klein, Jana 


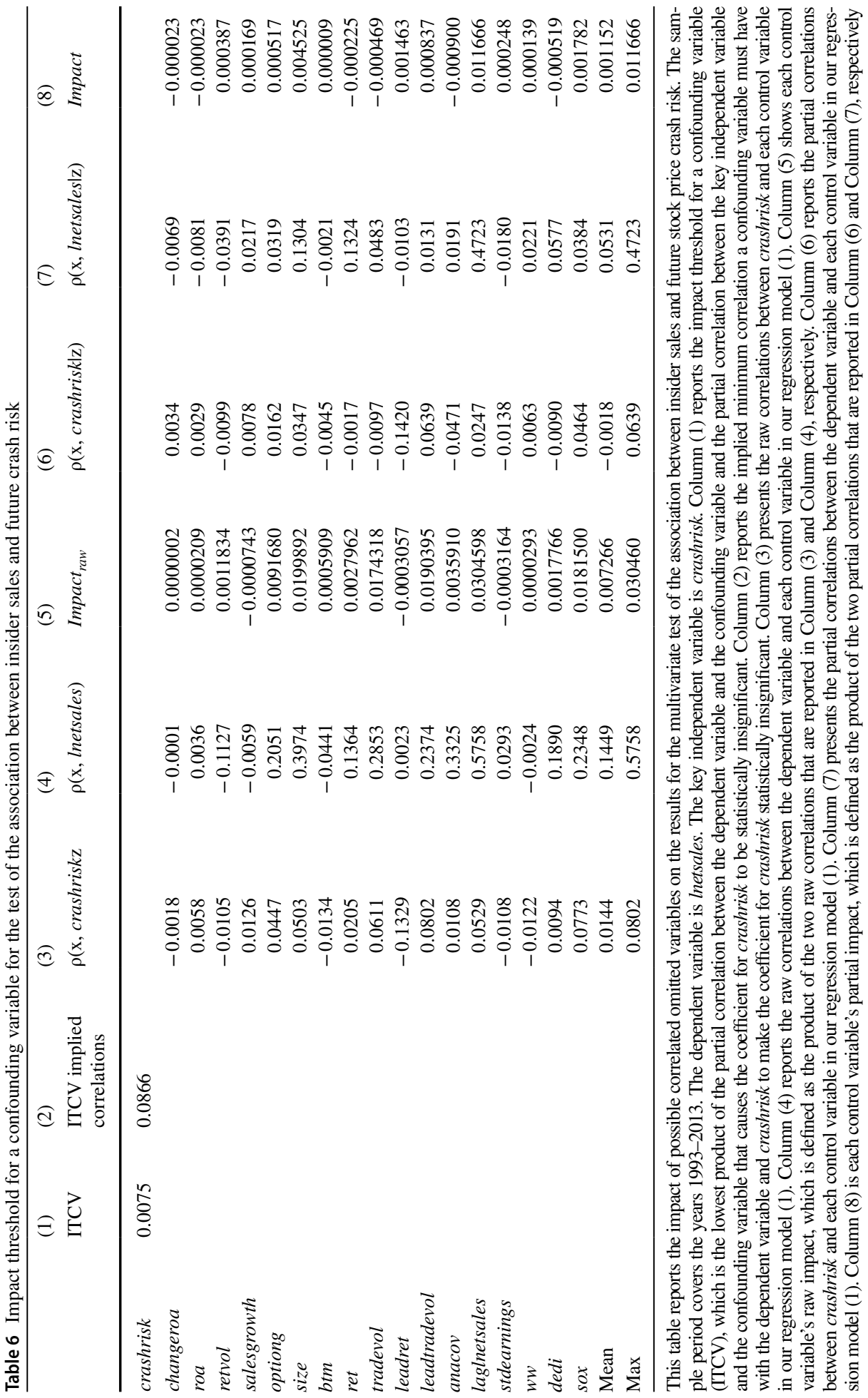


Fidrmuc, Wenrui Zhang, Tao Li, Yao Chen, Steven Wang, Bartolome Pascual-Fuster, and seminar participants at the 2019 American Economic Association annual meeting, 5th Annual International Corporate Governance Society Conference, 2018 Canadian Academic Accounting Association annual meeting, 30th Anniversary conference of Chinese Economic Association, 2016 European Financial Management Association annual meeting (a runner-up best paper), 2016 American Accounting Association annual meeting, 2016 International Rome conference on Money, Banking, and Finance, 2016 Financial Management Association European conference, 2016 Multinational Finance Society conference, and University of Warwick. We also thank Brian Bushee for sharing his institutional investor classification data. All errors remain our own.

Open Access This article is licensed under a Creative Commons Attribution 4.0 International License, which permits use, sharing, adaptation, distribution and reproduction in any medium or format, as long as you give appropriate credit to the original author(s) and the source, provide a link to the Creative Commons licence, and indicate if changes were made. The images or other third party material in this article are included in the article's Creative Commons licence, unless indicated otherwise in a credit line to the material. If material is not included in the article's Creative Commons licence and your intended use is not permitted by statutory regulation or exceeds the permitted use, you will need to obtain permission directly from the copyright holder. To view a copy of this licence, visit http://creativecommons.org/licenses/by/4.0/.

\section{Appendix: summary of variable definitions}

\begin{tabular}{|c|c|}
\hline Variables & Definitions \\
\hline crashrisk & $\begin{array}{l}1 \text { if a firm experiences one or more firm-specific weekly returns falling } 3.2 \text { standard } \\
\text { deviations below the mean of firm-specific weekly returns in a fiscal year, and } 0 \\
\text { otherwise. Our firm-specific weekly returns measure follows Kim et al. (2011a) }\end{array}$ \\
\hline ncskew & $\begin{array}{l}\text { The negative of the third moment of each stock's firm-specific daily returns follow- } \\
\text { ing Chen et al. (2001) }\end{array}$ \\
\hline duvol & $\begin{array}{l}\text { The standard deviation of "down"-week firm-specific weekly returns (scaled by the } \\
\text { number of "down"-weeks minus 1), divided by the standard deviation of "up"- } \\
\text { week firm-specific weekly returns (scaled by the number of "up"-weeks minus } \\
\text { 1) over a fiscal year. The firm-specific weekly returns measure follows Kim et al. } \\
\text { (2011a) }\end{array}$ \\
\hline lnetsales & $\begin{array}{l}\text { The natural logarithm of } 1 \text { plus the volume amount of net insider sales (i.e., insider } \\
\text { sales minus insider purchases) made by all the directors and officers over a year } \\
\text { ending } 3 \text { months prior to the beginning of the year for which crashrisk, ncskew, } \\
\text { and duvol are measured, and equals } 0 \text { when the volume amount of the net insider } \\
\text { sales is negative }\end{array}$ \\
\hline laglnetsales & $\begin{array}{l}\text { The natural logarithm of } 1 \text { plus the volume amount of net insider sales (i.e., insider } \\
\text { sales minus insider purchases) made by all the directors and officers in the year } \\
\text { ending } 15 \text { months prior to the beginning of the year for which crashrisk, ncskew, } \\
\text { and duvol are measured, and equals } 0 \text { when the volume amount of the net insider } \\
\text { sales is negative }\end{array}$ \\
\hline llaglnetsales & $\begin{array}{l}\text { The natural logarithm of } 1 \text { plus the volume amount of net insider sales (i.e., insider } \\
\text { sales minus insider purchases) made by all the directors and officers in the year } \\
\text { ending } 27 \text { months prior to the beginning of the year for which crashrisk, ncskew, } \\
\text { and duvol are measured, and equals } 0 \text { when the volume amount of the net insider } \\
\text { sales is negative }\end{array}$ \\
\hline nonofficerlnetsales & $\begin{array}{l}\text { The natural logarithm of } 1 \text { plus the volume amount of net insider sales (i.e., insider } \\
\text { sales minus insider purchases) made by all the non-officer employees over a year } \\
\text { ending } 3 \text { months prior to the beginning of year for which crashrisk, ncskew, and } \\
\text { duvol are measured, and equals } 0 \text { when the volume amount of the net insider sales } \\
\text { is negative }\end{array}$ \\
\hline
\end{tabular}


Table 7 Placebo test: the association between non-officer employees' stock sales and future stock price crash risk

\section{V}

Variables

Dependent variable = nonofficerlnetsales

\begin{tabular}{|c|c|}
\hline Intercept & $\begin{array}{l}-0.0768 \\
(0.741)\end{array}$ \\
\hline crashrisk & $\begin{array}{l}0.0611 \\
(0.374)\end{array}$ \\
\hline changeroa & $\begin{array}{l}0.0040 \\
(0.405)\end{array}$ \\
\hline roa & $\begin{array}{l}-0.0029 \\
(0.511)\end{array}$ \\
\hline retvol & $\begin{array}{l}0.2382 \\
(0.476)\end{array}$ \\
\hline salesgrowth & $\begin{array}{l}0.0024 \\
(0.422)\end{array}$ \\
\hline optiong & $\begin{array}{l}0.0144 * \\
(0.050)\end{array}$ \\
\hline size & $\begin{array}{l}0.2642 * * * \\
(<0.001)\end{array}$ \\
\hline btm & $\begin{array}{l}0.0019 \\
(0.487)\end{array}$ \\
\hline ret & $\begin{array}{l}0.3056 * * * \\
(<0.001)\end{array}$ \\
\hline tradevol & $\begin{array}{l}0.1515 * * * \\
(<0.001)\end{array}$ \\
\hline leadret & $\begin{array}{l}0.0147 \\
(0.682)\end{array}$ \\
\hline leadtradevol & $\begin{array}{l}0.0891 * * * \\
(0.001)\end{array}$ \\
\hline anacov & $\begin{array}{l}-0.0005 \\
(0.726)\end{array}$ \\
\hline nonofficerlaglnetsales & $\begin{array}{l}-0.1205^{* * *} \\
(<0.001)\end{array}$ \\
\hline stdearnings & $\begin{array}{l}-0.0001 * * \\
(0.035)\end{array}$ \\
\hline$w w$ & $\begin{array}{l}0.0722 \\
(0.404)\end{array}$ \\
\hline dedi & $\begin{array}{l}2.3204 * * * \\
(<0.001)\end{array}$ \\
\hline $\operatorname{sox}$ & $\begin{array}{l}0.0651 \\
(0.710)\end{array}$ \\
\hline Year-fixed effects & Included \\
\hline Industry-fixed effects & Included \\
\hline R-squared & 0.1298 \\
\hline Num. of observations & 32,326 \\
\hline
\end{tabular}


Table 7 (continued)
This table reports the OLS regression results for the placebo test which explores the association between non-officer employees' stock sales and future stock price crash risk. The sample period covers the years 1993-2013. The dependent variable is nonofficerlnetsales. The key independent variable is crashrisk. All the variables in the table are defined in the "Appendix". Year- and industry-fixed effects are included in the regressions but not reported for simplicity. The industry-fixed effects are based on the industry dummies constructed from the first two digits of SIC codes. The $p$ values in parentheses are based on robust standard errors clustered by firm. ***, **, *represent the $1 \%, 5 \%$, and $10 \%$ statistical significance levels (two-tailed), respectively

\begin{tabular}{|c|c|}
\hline Variables & Definitions \\
\hline$\overline{\text { nonofficerlaglnetsales }}$ & $\begin{array}{l}\text { The natural logarithm of } 1 \text { plus the volume amount of net insider sales (i.e., insider } \\
\text { sales minus insider purchases) made by all the non-officer employees over a year } \\
\text { ending } 15 \text { months prior to the beginning of year for which crashrisk, ncskew, and } \\
\text { duvol are measured, and equals } 0 \text { when the volume amount of the net insider sales } \\
\text { is negative }\end{array}$ \\
\hline$h p$ & $\begin{array}{l}\text { A financial constraint index }(h p) \text { developed by Hadlock and Pierce }(2010) \text {. } \\
h p=-0.737 * \text { totassets }+0.043^{*} \text { totassets }^{2}-0.040^{*} \text { age, where totassets is the natu- } \\
\text { ral logarithm of total assets capped at } \$ 4.5 \text { billion, and age is the number of years } \\
\text { for which a firm has been listed }\end{array}$ \\
\hline$\overline{w w}$ & $\begin{array}{l}\text { A financial constraint index }(w w) \text { developed by Whited and Wu (2006). } \\
w w=-0.091 * \text { cash_flow/ta }-0.062 * \text { dividend_dummy }+0.021 * \text { ltd/ta }-0.044 * \text { totas- } \\
\text { sets }+0.102 * \text { industry_sales_growth }-0.035^{*} \text { sales_growth, where cash_flow is } \\
\text { cash flow from operations divided by lagged total assets, dividend_dummy equals } \\
1 \text { if a firm has paid dividends, and } 0 \text { otherwise, ltd/ta is the ratio of long-term } \\
\text { debt to lagged total assets, totassets is the natural logarithm of lagged total } \\
\text { assets, industry_sales_growth is annual growth of industry sales at the three-digit } \\
\text { Standard Industrial Classification (SIC) level, and sales_growth is annual change } \\
\text { in sales divided by lagged sales }\end{array}$ \\
\hline$k z$ & $\begin{array}{l}\text { A financial constraint index }(\mathrm{kz}) \text { developed by Kaplan and Zingales }(1997) \text {. } \\
k z=-1.002 *(c f / t a)-39.368^{*}(\operatorname{div} / \mathrm{ta})-1.315^{*}(\mathrm{ca} / \mathrm{ta})+3.139 * l e v+0.283^{*} \mathrm{mt} b \text {, } \\
\text { where } c f / t a \text { is the ratio of cash flow to lagged book assets, div/ta is the ratio of } \\
\text { cash dividends to lagged book assets, ca/ta is the ratio of cash balance to lagged } \\
\text { book assets, } l e v \text { is the ratio of total debt to book assets, and } m t b \text { is the market-to- } \\
\text { book ratio }\end{array}$ \\
\hline payout & $\begin{array}{l}\text { The dividend payout ratio, which equals dividend payout divided by earnings before } \\
\text { interests and taxes }\end{array}$ \\
\hline changeroa & Return on assets for the next fiscal year divided by that for the current fiscal year \\
\hline roa & Return on assets at the end of the next fiscal year \\
\hline salesgrowth & $\begin{array}{l}\text { Sales revenues for the current fiscal year minus sales revenues for the previous fis- } \\
\text { cal year, scaled by sales revenues for the previous fiscal year }\end{array}$ \\
\hline optiong & The number of options grants at the end of the fiscal year \\
\hline ret & $\begin{array}{l}\text { Buy-and-hold abnormal stock returns of a firm in the fiscal year, which is measured } \\
\text { in the same window as our insider sales variable (i.e., lnetsales) is }\end{array}$ \\
\hline leadret & $\begin{array}{l}\text { Buy-and-hold abnormal stock returns of a firm in the fiscal year, which is measured } \\
\text { in the same window as our crash risk variables (i.e., crashrisk, ncskew, and duvol) } \\
\text { are }\end{array}$ \\
\hline size & $\begin{array}{l}\text { The natural logarithm of the market value of a firm's equity at the end of the fiscal } \\
\text { year }\end{array}$ \\
\hline
\end{tabular}


Table 8 Additional test: the association between insider sales and 27-month-ahead stock price crash risk

\begin{tabular}{|c|c|}
\hline Variables & $\begin{array}{l}\text { Dependent variable }=\text { lagl }- \\
\text { netsales }(27 \text { months } \\
\text { ahead) }\end{array}$ \\
\hline Intercept & $\begin{array}{l}-1.9435 * * * \\
(0.000)\end{array}$ \\
\hline crashrisk & $\begin{array}{l}0.1397^{*} \\
(0.083)\end{array}$ \\
\hline changeroa & $\begin{array}{l}-0.0334 * \\
(0.092)\end{array}$ \\
\hline roa & $\begin{array}{l}-0.0202 * * \\
(0.023)\end{array}$ \\
\hline retvol & $\begin{array}{l}-0.7105 \\
(0.112)\end{array}$ \\
\hline salesgrowth & $\begin{array}{l}0.0069 \\
(0.392)\end{array}$ \\
\hline optiong & $\begin{array}{l}0.0203^{* * * *} \\
(0.001)\end{array}$ \\
\hline size & $\begin{array}{l}0.4411^{* * * *} \\
(<0.001)\end{array}$ \\
\hline btm & $\begin{array}{l}-0.0008 \\
(0.787)\end{array}$ \\
\hline ret & $\begin{array}{l}0.7774 * * * \\
(<0.001)\end{array}$ \\
\hline tradevol & $\begin{array}{l}0.1720 * * * \\
(<0.001)\end{array}$ \\
\hline leadret & $\begin{array}{l}0.0180 \\
(0.739)\end{array}$ \\
\hline leadtradevol & $\begin{array}{l}0.0604 * * \\
(0.025)\end{array}$ \\
\hline anacov & $\begin{array}{l}0.0049 * * * \\
(<0.001)\end{array}$ \\
\hline llaglnetsales & $\begin{array}{l}0.4757 * * * \\
(<0.001)\end{array}$ \\
\hline stdearnings & $\begin{array}{l}-0.0002 * * * \\
(0.002)\end{array}$ \\
\hline$w w$ & $\begin{array}{l}0.2924 \\
(0.173)\end{array}$ \\
\hline dedi & $\begin{array}{l}3.4802^{* * * *} \\
(<0.001)\end{array}$ \\
\hline sox & $\begin{array}{l}1.9482 * * * \\
(<0.001)\end{array}$ \\
\hline Year-fixed effects & Included \\
\hline Industry-fixed effects & Included \\
\hline R-squared & 0.4030 \\
\hline Num. of observations & 25,106 \\
\hline
\end{tabular}


Table 8 (continued)
This table shows the OLS regression result for the test of the association between insider sales and 27- month-ahead stock price crash risk. The sample period covers the years 1993-2013. The dependent variable is laglnetsales, and the key independent variable is crashrisk. All the variables in the table are defined in the "Appendix". Year- and industry-fixed effects are included in the regressions but not reported for brevity. The industry-fixed effects are based on the industry dummies constructed from the first two digits of SIC codes. The $p$ values in parentheses are based on robust standard errors clustered by firm. $* * *, * *, *$ represent the $1 \%, 5 \%$, and $10 \%$ statistical significance levels (two-tailed), respectively

\begin{tabular}{ll}
\hline Variables & Definitions \\
\hline btm & The book value of firm equity divided by the market value of firm equity at the end \\
& of the fiscal year \\
Daily dollar trading volume (i.e., the closing price at a given date times the number & of shares traded at that date) (in millions of U.S dollars) averaged over a fiscal \\
tradevol & year for a firm. tradevol is measured in the same window as that of our insider \\
& sales variable (i.e., lnetsales) \\
& Daily dollar trading volume (i.e., the closing price at a given date times the number \\
& of shares traded at that date) (in millions of U.S dollars) averaged over a fiscal \\
& year for a firm. leadtradevol is measured in the same window as that of our crash \\
& risk variables (i.e., crashrisk, ncskew, and duvol) \\
leadtradevol & The number of analysts that make at least one earnings forecast for a firm in the \\
& fiscal year \\
Dedicated institutional investors' stock ownership as a percentage of a firm's out- \\
standing shares at the end of the fiscal year \\
0 if a firm is in the pre-SOX period (i.e., years 1993-2002), and 1 if a firm is in \\
the post-SOX period (i.e., years 2003-2013), which excludes the financial crisis \\
period 2007-2009 \\
The standard deviation of daily market excess return over a 12-month period ending \\
at the end of the fiscal year \\
The three-year moving sum of the absolute value of annual abnormal accruals, a \\
measure of financial opacity developed by Hutton et al. (2009) \\
The standard deviation of income before extraordinary items in the current and \\
previous four fiscal years \\
stdearnings
\end{tabular}

\section{References}

Aboody D, Lev B (2000) Information asymmetry, R\&D, and insider gains. J Finance 55:2747-2766

Acharya V, Phillippon T, Richardson M, Roubini N (2009) The financial crisis of 2007-2009: causes and remedies. In: Acharya V, Richardson M (eds) Restoring financial stability. Wiley, New York

Adrian T, Shin HS (2010) The changing nature of financial intermediation and the financial crisis of 20072009. Annu Rev Econ 2:603-618

Agrawal A, Cooper T (2015) Insider trading before accounting scandals. J Corp Finance 34:169-190

Amel-Zedeh A, Faasse J, Lotz J (2019) Are all insider sales created equal? first evidence from supplementary disclosures in SEC filings. Working paper, University of Oxford, University Cambridge, and University of Mannheim

Amin KI, Lee CMC (1997) Option trading, price discovery, and earnings news dissemination. Contemp Acc Res 14:153-192 
Arping S, Sautner Z (2013) Did SOX Section 404 make firms less opaque? evidence from cross-listed firms. Contemp Acc Res 30:1133-1165

Ashbaugh-Skaife H, Collins DW, Kinney WR Jr, LaFond R (2009) The effect of SOX internal control deficiencies on firm risk and cost of equity. J Acc Res 47:1-43

Ataullah A, Goergen M, Le H (2014) Insider trading and financing constraints. Financ Rev 49:685-712

Badertscher BA, Hribar SP, Jenkins NT (2011) Informed trading and the market reaction to accounting restatements. Acc Rev 86:1519-1547

Baginski SP, Campbell JL, Hinson LA, Koo DS (2018) Do career concerns affect the delay of bad news disclosure? Acc Rev 93:61-95

Beneish MD (1999) Incentives and penalties related to earnings overstatements that violate GAAP. Acc Rev 74:425-457

Beneish MD, Vargus ME (2002) Insider trading, earnings quality, and accrual mispricing. Acc Rev 77:755-791

Bettis JC, Coles JL, Lemmon ML (2000) Corporate policies restricting trades by insiders. J Financ Econ 57:191-220

Billings MB, Cedergren MC (2015) Strategic silence, insider selling and litigation risk. J Acc Econ 59:119-142

Callen JL, Fang X (2015) Short interest and stock price crash risk. J Bank Financ 60:181-194

Campello M, Graham JR, Harvey CR (2010) The real effects of financial constraints: evidence from a financial crisis. J Financ Econ 97:470-487

Carpenter JN, Remmers B (2001) Executive stock option exercises and inside information. J Bus $74: 513-534$

Chen J, Hong H, Stein JC (2001) Forecasting crashes: trading volume, past returns, and conditional skewness in stock prices. J Financ Econ 61:345-381

Chen X, Harford J, Li K (2007) Monitoring: which institutions matter. J Financ Econ 86:279-305

Chen T, Harford J, Lin C (2015) Do analyst matter for governance? evidence from natural experiments. J Financ Econ 115:383-410

Cheng Q, Lo K (2006) Insider trading and voluntary disclosures. J Acc Res 44:815-848

Darrough M, Rangan S (2005) Do insiders manipulate earnings when they sell their shares in an initial public offering. J Acc Res 43:1-33

Dechow PM, Lawrence A, Ryans JP (2016) SEC comment letters and insider sales. Acc Rev 91:401-439

DeFond ML, Hung M, Li S, Li Y (2015) Does mandatory IFRS adoption affect crash risk? Acc Rev 90:265-299

Denis DJ, Sibilkov V (2010) Financial constraints, investment, and the value of cash holdings. Rev Financ Stud 23:247-269

Fazzari SM, Hubbard RG, Petersen BC (1988) Financing constraints and corporate investment. Brook Pap Econ Act 1988:141-195

Fidrmuc JP, Goergen M, Renneboog L (2006) Insider trading, news releases and ownership concentration. J Financ 61:2931-2973

Fishman MJ, Hagerty KM (1992) Insider trading and the efficiency of stock prices. RAND J Econ 23:106-122

Francis B, Hasan I, Li L (2016) Abnormal real operations, real earnings management, and subsequent crashes in stock prices. Rev Quant Financ Acc 46:217-260

Frank KA (2000) Impact of a confounding variable on a regression coefficient. Sociol Methods Res 29:147-194

Frankel R, Li X (2004) Characteristics of a firm's information environment and the information asymmetry between insiders and outsiders. J Acc Econ 37:229-259

Garfinkel JA (1997) New evidence on the effects of federal regulations on insider trading: the Insider Trading and Securities Fraud Enforcement Act. J Corp Finance 3:89-111

Glosten LR, Milgrom PR (1985) Bid, ask, and transaction prices in a specialist market with heterogeneously informed traders. J Financ Econ 14:71-100

Gosnell T, Keown AJ, Pinkerton JM (1992) Bankruptcy and insider trading: differences between exchange-listed and OTC firms. J Financ 47:349-362

Grossman SJ, Stiglitz JE (1980) On the impossibility of informationally efficient markets. Am Econ Rev 70:393-408

Hadlock CJ, Pierce JR (2010) New evidence on measuring financial constraints: moving beyond the KZ index. Rev Financ Stud 23:1909-1940

He G (2015) The effect of CEO inside debt holdings on financial reporting quality. Rev Acc Stud 20:501-536 
He G, Marginson D (2020) The impact of insider trading on analyst coverage and forecasts. Acc Res J 33:499-521

He G, Ren HM (2020) Are financially constrained firms susceptible to a stock price crash? Working paper, Durham University, https://ssrn.com/abstract=3021307

He G, Bai L, Ren HM (2019) Analyst coverage and future stock price crash risk. J Appl Acc Res 20:63-77

Huddart SJ, Ke B (2007) Information asymmetry and cross-sectional variation in insider trading. Contemp Acc Res 24:195-232

Huddart S, Ke B, Shi C (2007) Jeopardy, non-public information, and insider trading around SEC 10-K and 10-Q filings. J Acc Econ 43:3-36

Hutton AP, Marcus AJ, Tehranian H (2009) Opaque financial reports, R2, and crash risk. J Financ Econ 94:67-86

Hyland DC, Sarkar SK, Tripathy N (2003) Insider trading when an underlying option is present. Financ Anal J 59:69-77

Iliev P (2010) The effect of SOX Section 404: costs, earnings quality, and stock prices. J Financ 65:1163-1196

Jaggi B, Winder JP, Lee C (2010) Is there a future for fair value accounting after the 2008-2009 financial crisis? Rev Pac Basin Financ Mark Policy 13:469-493

Jagolinzer AD, Larcker DF, Taylor DJ (2011) Corporate governance and the information content of insider trades. J Acc Res 49:1249-1274

Jeng LA, Metrick A, Zeckhauser R (2003) Estimating the returns to insider trading: a performance-evaluation perspective. Rev Econ Stat 85:453-471

Jensen MC, Meckling WH (1976) Theory of the firm: managerial behavior, agency costs, and ownership structure. J Financ Econ 3:305-360

Jin L, Myers SC (2006) R2 around the world: new theory and new tests. J Financ Econ 79:257-292

John K, Lang LHP (1991) Strategic insider trading around dividend announcements: theory and evidence. J Financ 46:1361-1389

Johnson SA, Ryan HE, Tian YS (2009) Managerial incentives and corporate fraud: the sources of incentives matter. Rev Financ 13:115-145

Kallunki J, Kallunki J, Nilsson H, Puhakka M (2018) Do an insider's wealth and income matter in the decision to engage in insider trading? J Financ Econ 130:135-165

Kao EH, Huang H, Fund H, Liu X (2020) Co-opted directors, gender diversity, and crash risk: evidence from China. Rev Quant Financ Acc 55:461-500

Kaplan SN, Zingales L (1997) Do investment-cash flow sensitivities provide useful measures of financing constraints. Q J Econ 112:169-215

Ke B, Huddart S, Petroni K (2003) What insiders know about future earnings and how they use it: evidence from insider trades. J Acc Econ 35:315-346

Kim J-B, Li Y, Zhang L (2011a) Corporate tax avoidance and stock price crash risk: firm-level analysis. J Financ Econ 100:639-662

Kim J-B, Li Y, Zhang L (2011b) CFOs versus CEOs: equity incentives and crashes. J Financ Econ 101:713-730

Kothari SP, Shu S, Wysocki PD (2009) Do managers withhold bad news? J Acc Res 47:241-276

Kyle AS (1985) Continuous auctions and insider trading. Econometrica 53:1315-1335

Lakonishok J, Lee I (2001) Are insider trades informative. Rev Financ Stud 14:79-111

Lamont O, Polk C, Saá-Requejo J (2001) Financial constraints and stock returns. Rev Financ Stud 14:529-554

Larcker DF, Rusticus TO (2010) On the use of instrumental variables in accounting research. J Acc Econ 49:186-205

Lee W, Wang L (2017) Do political connections affect stock price crash risk? Firm-level evidence from China. Rev Quant Financ Account 48:643-676

Lustgarten S, Mande V (1995) Financial analysts' earnings forecasts and insider trading. J Acc Public Policy 14:233-261

Niehaus G, Roth G (1999) Insider trading, equity issues, and CEO turnover in firms subject to securities class action. Financ Manag 28:52-72

Noe CF (1999) Voluntary disclosures and insider transactions. J Acc Econ 27:305-326

Ofek E, Yermack D (2000) Taking stock: equity-based compensation and the evolution of managerial ownership. J Financ 55:1367-1384

Piotroski JD, Roulstone DT (2005) Do insider trades reflect both contrarian beliefs and superior knowledge about future cash flow realization. J Acc Econ 39:55-81 
Rozeff MS, Zaman MA (1998) Overreaction and insider trading: evidence from growth and value portfolios. J Financ 53:701-716

Seyhun HN (1986) Insiders' profits, costs of trading, and market efficiency. J Financ Econ 16:189-212

Seyhun HN, Bradley M (1997) Corporate bankruptcy and insider trading. J Bus 70:189-216

Skaife HA, Veenman DV, Wangerin D (2013) Internal control over financial reporting and managerial rent extraction: evidence from the profitability of insider trading. J Acc Econ 55:91-110

Thevenot M (2012) The factors affecting illegal insider trading in firms with violations of GAAP. J Acc Econ 53:375-390

Whited TM, Wu G (2006) Financial constraints risk. Rev Financ Stud 19:531-559

Publisher's Note Springer Nature remains neutral with regard to jurisdictional claims in published maps and institutional affiliations. 